\title{
A global 3-D CTM evaluation of black carbon in the Tibetan Plateau
}

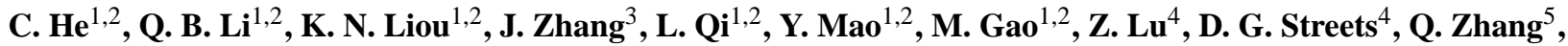 \\ M. M. Sarin ${ }^{6}$, and K. $\operatorname{Ram}^{7}$ \\ ${ }^{1}$ Department of Atmospheric and Oceanic Sciences, University of California, Los Angeles, CA, USA \\ ${ }^{2}$ Joint Institute for Regional Earth System Science and Engineering, University of California, Los Angeles, CA, USA \\ ${ }^{3}$ Department of Atmospheric and Oceanic Sciences, School of Physics, Peking University, Beijing, China \\ ${ }^{4}$ Decision and Information Sciences Division, Argonne National Laboratory, Argonne, \\ Illinois, USA \\ ${ }^{5}$ Center for Earth System Science, Tsinghua University, Beijing, China \\ ${ }^{6}$ Department of Geosciences, Physical Research Laboratory, Ahmedabad, India \\ ${ }^{7}$ Institute of Environment and Sustainable Development, Banaras Hindu University, Varanasi, India
}

Correspondence to: C. He (cenlinhe@ atmos.ucla.edu)

Received: 15 February 2014 - Published in Atmos. Chem. Phys. Discuss.: 8 March 2014

Revised: 22 May 2014 - Accepted: 4 June 2014 - Published: 11 July 2014

\begin{abstract}
We systematically evaluate the black carbon (BC) simulations for 2006 over the Tibetan Plateau by a global 3D chemical transport model (CTM) (GEOS-Chem) driven by GEOS-5 assimilated meteorological fields, using in situ measurements of BC in surface air, BC in snow, and BC absorption aerosol optical depth (AAOD). Using improved anthropogenic $\mathrm{BC}$ emission inventories for Asia that account for rapid technology renewal and energy consumption growth (Zhang et al., 2009; Lu et al., 2011) and improved global biomass burning emission inventories that account for small fires (van der Werf et al., 2010; Randerson et al., 2012), we find that model results of both BC in surface air and in snow are statistically in good agreement with observations (biases $<15 \%$ ) away from urban centers. Model results capture the seasonal variations of the surface $\mathrm{BC}$ concentrations at rural sites in the Indo-Gangetic Plain, but the observed elevated values in winter are absent. Modeled surface-BC concentrations are within a factor of 2 of the observations at remote sites. Part of the discrepancy is explained by the deficiencies of the meteorological fields over the complex Tibetan terrain. We find that $\mathrm{BC}$ concentrations in snow computed from modeled BC deposition and GEOS-5 precipitation are spatiotemporally consistent with observations $(r=0.85)$. The computed $\mathrm{BC}$ concentrations in snow are a factor of 2-4 higher than the observations at several Himalayan sites because of excessive $\mathrm{BC}$ deposition. The $\mathrm{BC}$ concentrations in snow are biased low by a factor of 2 in the central plateau,
\end{abstract}

which we attribute to the absence of snow aging in the CTM and strong local emissions unaccounted for in the emission inventories. Modeled BC AAOD is more than a factor of 2 lower than observations at most sites, particularly to the northwest of the plateau and along the southern slopes of the Himalayas in winter and spring, which is attributable in large part to underestimated emissions and the assumption of external mixing of $\mathrm{BC}$ aerosols in the model. We find that assuming a $50 \%$ increase of $\mathrm{BC}$ absorption associated with internal mixing reduces the bias in modeled $\mathrm{BC}$ AAOD by $57 \%$ in the Indo-Gangetic Plain and the northeastern plateau and to the northeast of the plateau, and by $16 \%$ along the southern slopes of the Himalayas and to the northwest of the plateau. Both surface BC concentration and AAOD are strongly sensitive to anthropogenic emissions (from China and India), while BC concentration in snow is especially responsive to the treatment of $\mathrm{BC}$ aerosol aging. We find that a finer model resolution $\left(0.5^{\circ} \times 0.667^{\circ}\right.$ nested over Asia) reduces the bias in modeled surface-BC concentration from 15 to $2 \%$. The large range and non-homogeneity of discrepancies between model results and observations of $\mathrm{BC}$ across the Tibetan Plateau undoubtedly undermine current assessments of the climatic and hydrological impact of $\mathrm{BC}$ in the region and thus warrant imperative needs for more extensive measurements of $\mathrm{BC}$, including its concentration in surface air and snow, AAOD, vertical profile and deposition. 


\section{Introduction}

Black carbon (BC) is the most important light-absorbing aerosol formed during incomplete combustion (Bond et al., 2013, and references therein), with major sources from fossil fuel and biofuel combustion and open biomass burning (Bond et al., 2004). BC warms the atmosphere by strongly absorbing solar radiation in the visible and the near-infrared (Ramanathan and Carmichael, 2008), influences cloud formation as cloud condensation nuclei (Jacobson, 2006), and accelerates snow and ice melting by significantly reducing snow and ice albedo (i.e., the snow-albedo effect) (Hansen and Nazarenko, 2004; Flanner et al., 2007). With an estimated global climate forcing of $+1.1 \mathrm{~W} \mathrm{~m}^{-2}$, $\mathrm{BC}$ is now considered the second most important human emission in terms of its climate forcing in the present-day atmosphere after carbon dioxide (Ramanathan and Carmichael, 2008; Bond et al., 2013). The regional warming effect of $\mathrm{BC}$ can be even stronger, particularly over snow-covered regions (Jacobson, 2004; Flanner et al., 2007, 2009). There is ample evidence that $\mathrm{BC}$ aerosols deposited on Tibetan glaciers have been a significant contributing factor to observed rapid glacier retreat in the region (e.g., Xu et al., 2009). It has also been proposed that the radiative forcing from ever-increasing deposition of $\mathrm{BC}$ in snow was an important cause for the retreat of Alpine glaciers from the last Little Ice Age through the mid-19th century (Painter et al., 2013).

The Tibetan Plateau is the highest plateau in the world with the largest snow and ice mass outside the polar regions (Xu et al., 2009). The Tibetan glaciers and the associated snowmelt are the primary source of freshwater supply for drinking, agricultural irrigation, and hydropower for more than 1 billion people in Asia (Immerzeel et al., 2010). The plateau also plays a critical role in regulating the Asian hydrological cycle. Changes of snow cover affect heat flux and water exchange between the surface and the atmosphere, and further disturb the formation of the Asian monsoon (Lau and Kim, 2006).

Observations have shown remarkable warming and accelerated glacier retreat in the Tibetan Plateau in the past decades (Qin et al., 2006; Prasad et al., 2009). Ramanathan et al. $(2005,2007)$ argued that the ever-increasing amount of $\mathrm{BC}$ transported to the Himalayas accounts for half of the observed warming in the region, comparable to the warming attributable to greenhouse gases (Barnett et al., 2005). Recent studies reaffirmed a strong BC-induced regional warming over the plateau that results in more than $1 \%$ decrease of snow/ice cover (Lau et al., 2010; Menon et al., 2010), 2$5 \%$ reduction of snow albedo (Yasunari et al., 2010), and an increase of runoff in early spring (Qian et al., 2011). Surrounded by the world's two largest $\mathrm{BC}$ source regions, south and east Asia (Lamarque et al., 2010), the plateau has received an increasing BC deposition from 1951 to 2000, particularly after 1990 (Ming et al., 2008). Recent studies have shown that the amount of $\mathrm{BC}$ transported to the plateau has increased by $41 \%$ from 1996 to 2010, with south and east Asia accounting for $67 \%$ and for $17 \%$ on an annual basis (Lu et al., 2012). The modeling study by Kopacz et al. (2011) suggested that long-range transport from Middle East, Europe, and northern Africa also contributes to the BC deposition over the plateau.

The climatic effects of $\mathrm{BC}$ over the Tibetan Plateau are not well understood, with large uncertainties in the estimates of $\mathrm{BC}$ radiative forcing (e.g., Flanner et al., 2007; Kopacz et al., 2011; Ming et al., 2013). Accurate assessment of BCrelated radiative forcing in the Tibetan Plateau critically depends on reliable model simulations of $\mathrm{BC}$ emissions, transport and subsequent deposition, and vertical distribution over the plateau. Previous modeling studies have found invariably large discrepancies with observations. For example, the simulations of surface BC at several sites in the southern slope of the Himalayas are biased low by more than a factor of 2, particularly in winter and spring in regional, multiscale and global models (Nair et al., 2012; Moorthy et al., 2013). Fu et al. (2012) showed that surface-BC concentrations simulated by a global chemical transport model (CTM) are more than $50 \%$ lower than observations in China in general and across the Tibetan Plateau in particular. A global CTM study (Kopacz et al., 2011) and a global climate model (GCM) study (Qian et al., 2011) both showed large differences between modeled and observed BC concentration in snow over the plateau. Sato et al. (2003) and Bond et al. (2013) pointed out large underestimates of BC absorption aerosol optical depth (AAOD) in previous models compared with Aerosol Robotic Network (AERONET) retrievals.

In this study we seek to understand the capability of a global 3-dimensional CTM (GEOS-Chem) in simulating $\mathrm{BC}$ in the Tibetan Plateau and the associated discrepancies between model results and observations. The GEOS-Chem model has been widely used in previous studies to understand $\mathrm{BC}$ emissions, transport and deposition in the plateau (Kopacz et al., 2011), in China (Fu et al., 2012), over Asia (Park et al., 2005), in the Arctic (Wang et al., 2011) and globally (Wang et al., 2014). To our knowledge, this is the first attempt to systematically evaluate a global simulation of $\mathrm{BC}$ in the Tibetan Plateau using all three types of available in situ measurements: $\mathrm{BC}$ in surface air, $\mathrm{BC}$ in snow, and BC AAOD. We further delineate the effects of anthropogenic $\mathrm{BC}$ emissions from China and India, $\mathrm{BC}$ aging process and model resolution on the simulation. Potential factors driving model-versus-observation discrepancies are also examined, which gives implications for improving the estimate of BC climatic effects. Observations and model description are presented in Sect. 2. Simulations of surface BC, BC in snow and BC AAOD are discussed in Sect. 3. Sensitivity and uncertainty analyses are in Sects. 4, 5 and 6. Finally, summary and conclusions are given in Sect. 7. 


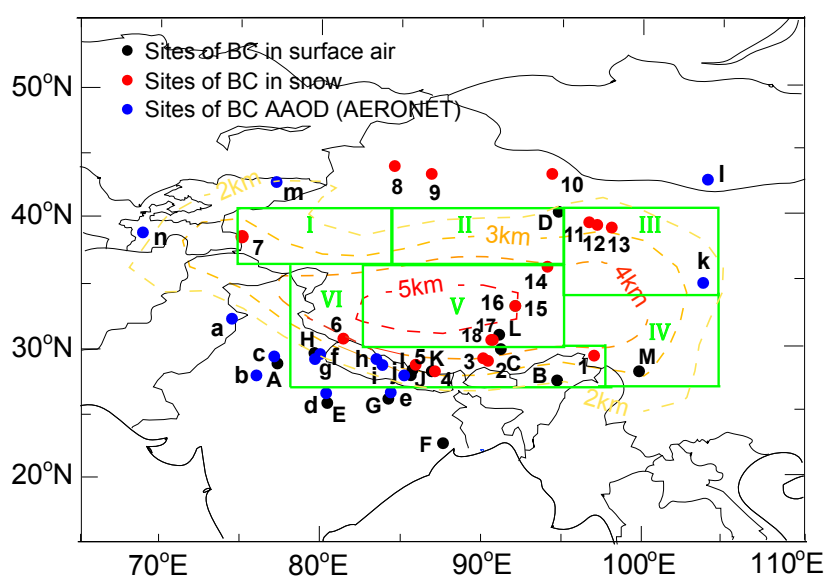

Figure 1. $\mathrm{BC}$ measurements at sites in and around the Tibetan Plateau (see also Tables 1, 2 and 3). Black circles are surface measurements: Delhi (A), Dibrugarh (B), Lhasa (C), Dunhuang (D), Kanpur (E), Kharagpur (F), Gandhi College (G), Manora Peak (H), Langtang (I), Nagarkot (J), Nepal Climate Observatory at Pyramid (NCOP, K), Nam Co Observational Station (NCOS, L), Zhuzhang (M). Red circles are measurements of BC in snow: Zuoqiupu (1), Qiangyong (2), Noijin Kangsang (3), East Rongbuk (4), Kangwure (5), Namunani (6), Mt. Muztagh (7), Haxilegen Riverhead (8), Urumqi Riverhead (9), Miao’ergou No. 3 (10), Laohugou No. 12 (11), Qiyi (12), 1 July glacier (13), Meikuang (14), Tanggula (15), Dongkemadi (16), La'nong (17), Zhadang (18). Blue circles are BC AAOD measurements: Lahore (a), Jaipur (b), Gual_Pahari (c), Kanpur (d), Gandi college (e), Nainital (f), Pantnagar (g), Jomsom (h), Pokhara (i), Kathmandu University (j), Semi-Arid Climate and Environment Observatory of Lanzhou University (SACOL, k), Dalanzadgad (l), Issyk-Kul (m), Dushanbe (n). The rectangles are the six sub-regions: the northwestern plateau (I), the northern plateau (II), the northeastern plateau (III), the southeastern plateau (IV), the central plateau (V), and the Himalayas (VI). Topography is also shown (dashed colored contours).

\section{Method}

\subsection{Observations}

For the sake of clarity, we define here the Tibetan Plateau roughly as the region in $28-40^{\circ} \mathrm{N}$ latitudes and $75-105^{\circ} \mathrm{E}$ longitudes. We also define several sub-regions of the plateau and adjacent regions (Fig. 1): the central plateau $\left(30-36^{\circ} \mathrm{N}\right.$, $\left.82-95^{\circ} \mathrm{E}\right)$, the northwestern plateau $\left(36-40^{\circ} \mathrm{N}, 75-85^{\circ} \mathrm{E}\right)$, the northeastern plateau $\left(34-40^{\circ} \mathrm{N}, 95-105^{\circ} \mathrm{E}\right)$, the southeastern plateau $\left(28-34^{\circ} \mathrm{N}, 95-105^{\circ} \mathrm{E}\right)$, to the north of the plateau $\left(40-50^{\circ} \mathrm{N}, 85-95^{\circ} \mathrm{E}\right)$, to the northwest of the plateau $\left(40-50^{\circ} \mathrm{N}, 70-85^{\circ} \mathrm{E}\right)$, to the northeast of the plateau (40$50^{\circ} \mathrm{N}, 95-105^{\circ} \mathrm{E}$ ), and the Himalayas. There are rather limited measurements of $\mathrm{BC}$ in the Tibetan Plateau. Figure 1 shows sites with measurements of $\mathrm{BC}$ surface concentration, concentration in snow, and AAOD in the region.

\subsubsection{BC surface concentration}

There are 13 sites with monthly or seasonal measurements of surface BC concentration (Table 1 and Fig. 1). Observations are available for 2006 at nine of the sites. Four sites provide observations for 1999-2000, 2004-2005 or 20082009. We distinguish these sites as urban, rural, or remote sites based upon annual mean surface-BC concentration, following Zhang et al. (2008). The concentration is typically higher than $5 \mu \mathrm{g} \mathrm{m}^{-3}$ at urban sites (within urban centers or near strong local residential and vehicular emissions), in the range of $2-5 \mu \mathrm{g} \mathrm{m}^{-3}$ at rural sites, and less than $2 \mu \mathrm{g} \mathrm{m}^{-3}$ at more remote, pristine sites.

Ganguly et al. (2009b) retrieved surface BC concentration at Gandhi College $\left(25.9^{\circ} \mathrm{N}, 84.1^{\circ} \mathrm{E}\right.$; $158 \mathrm{~m}$ a.s.l.) by combining aerosol optical properties from AERONET measurements and aerosol extinction profiles from Cloud-Aerosol Lidar with Orthogonal Polarization (CALIOP) observations. The retrieval is rather sensitive to errors in the aerosol single scattering albedo, size distribution and vertical profiles derived from the observations (Ganguly et al., 2009a). Measurements at Delhi $\left(28.6^{\circ} \mathrm{N}, 77.2^{\circ} \mathrm{E} ; 260 \mathrm{~m}\right.$ a.s.l.), Digrugarh $\left(27.3^{\circ} \mathrm{N}, 94.6^{\circ} \mathrm{E}\right.$; $111 \mathrm{~m}$ a.s.1.), Kharagpur $\left(22.5^{\circ} \mathrm{N}\right.$, 87. $5^{\circ} \mathrm{E}, 22 \mathrm{ma.s.1}$.) and Nepal Climate Observatory at Pyramid (NCOP, $28.0^{\circ} \mathrm{N}, 86.8^{\circ} \mathrm{E} ; 5079 \mathrm{~m}$ a.s.l.) used an aethalometer (Beegum et al., 2009; Pathak et al., 2010) or a multi-angle absorption photometer (Bonasoni et al., 2010; Nair et al., 2012). The uncertainties of these measurements stem mainly from the interference from other components in the aerosol samples (Bond et al., 1999; Petzold and Schonlinner, 2004) and the shadowing effects under high filter loads (Weingartner et al., 2003). BC concentrations at the other sites were derived from measurements of the thermal-optical reflectance or thermal-optical transmittance (Carrico et al., 2003; Qu et al., 2008; Zhang et al., 2008; Ming et al., 2010; Ram et al., 2010a,b). These measurements are strongly influenced by the temperature chosen to separate $\mathrm{BC}$ and organic carbon (OC) (Schmid et al., 2001; Chow et al., 2004).

\subsubsection{BC concentration in snow}

There are 16 sites with monthly or seasonal measurements of BC concentration in snow during 1999-2007 and two with annual measurements (Xu et al., 2006, 2009; Ming et al., 2009a, b, 2012, 2013). These sites are at high-elevation (> $3500 \mathrm{~m}$ a.s.1.), remote locations in the Himalayas and other parts of the plateau (Table 2 and Fig. 1). The snow and ice samples taken from these sites were heated and filtered through fiber filters in the laboratory. Thermal techniques (Cachier and Pertuisot, 1994; Chow et al., 2004) were then used to isolate $\mathrm{BC}$ from other constituents (especially OC) in the filters, followed by analysis using carbon analyzers including heating-gas chromatography (Xu et al., 2006), optical carbon analysis (Chow et al., 2004) and coulometric titration-based analysis (Cachier and Pertuisot, 1994). The 
Table 1. Observed and simulated surface-BC concentrations over the Tibetan Plateau (see also Fig. 1).

\begin{tabular}{|c|c|c|c|c|c|c|c|c|c|c|c|c|}
\hline \multirow[t]{2}{*}{ Region } & \multirow[t]{2}{*}{ Site } & \multirow{2}{*}{$\begin{array}{l}\text { Lat. } \\
\left({ }^{\circ} \mathrm{N}\right)\end{array}$} & \multirow{2}{*}{$\begin{array}{l}\text { Long. } \\
\left({ }^{\circ} \mathrm{E}\right)\end{array}$} & \multirow{2}{*}{$\begin{array}{l}\text { Elev. } \\
\text { (m) }\end{array}$} & \multirow[t]{2}{*}{ Time } & \multirow[t]{2}{*}{ Freq. } & \multirow[t]{2}{*}{ Technique $^{\mathrm{a}}$} & \multicolumn{4}{|c|}{ Surface $B C\left(\mu \mathrm{g} \mathrm{m}^{-3}\right)$} & \multirow[b]{2}{*}{ Exp. $D^{f}$} \\
\hline & & & & & & & & Obs. $^{\text {b }}$ & Exp. $A^{c}$ & Exp. $B^{d}$ & Exp. $C^{e}$ & \\
\hline \multirow[t]{2}{*}{ Urban } & Delhi & 28.6 & 77.2 & 260 & 2006 & monthly & aethalometer & $13.5^{[1]}$ & $2.6(1.6-4.7)$ & 1.7 & 2.6 & 2.6 \\
\hline & Dibrugarh & 27.3 & 94.6 & 111 & 2008-2009 & monthly & aethalometer & $8.9^{[2]}$ & $0.8(0.5-1.5)$ & 0.5 & 0.9 & 1.6 \\
\hline \multirow[t]{2}{*}{ - } & Lhasa & 29.7 & 91.1 & 3663 & 2006 & monthly & TOR & $3.7^{[3]}$ & $0.08(0.05-0.14)$ & 0.07 & 0.09 & 0.05 \\
\hline & Dunhuang & 40.2 & 94.7 & 1139 & 2006 & monthly & TOR & $4.1^{[3]}$ & $0.1(0.08-0.24)$ & 0.2 & 0.1 & 0.3 \\
\hline \multirow[t]{3}{*}{ Rural } & Kharagpur & 22.5 & 87.5 & 28 & 2006 & monthly & aethalometer & $5.5^{[4]}$ & $4.2(2.5-8.4)$ & 2.4 & 4.2 & 6.1 \\
\hline & Kanpur & 26.4 & 80.3 & 142 & 2006 & monthly & TOT & $3.7^{[5]}$ & $3.1(1.0-5.8)$ & 2.2 & 3.1 & 2.8 \\
\hline & Gandhi College & 25.9 & 84.1 & 158 & 2006 & monthly & retrieval & $4.8^{[6]}$ & $4.6(2.9-8.5)$ & 3.2 & 4.6 & 5.0 \\
\hline \multirow[t]{6}{*}{ Remote } & Nagarkot & 27.7 & 85.5 & 2150 & 1999-2000 & seasonal & TOT & $1.0^{[7]}$ & $0.8(0.5-1.3)$ & 0.7 & 0.8 & 0.7 \\
\hline & NCOP & 28.0 & 86.8 & 5079 & 2006 & monthly & MAAP & $0.2^{[8]}$ & $0.07(0.05-0.13)$ & 0.07 & 0.08 & 0.07 \\
\hline & Manora Peak & 29.4 & 79.5 & 1950 & 2006 & monthly & TOT & $1.1^{[9]}$ & $1.3(0.9-2.2)$ & 1.2 & 1.3 & 1.2 \\
\hline & NCOS & 30.8 & 91.0 & 4730 & 2006 & monthly & TOR & $0.1^{[10]}$ & $0.08(0.05-0.15)$ & 0.07 & 0.09 & 0.04 \\
\hline & Langtang & 28.1 & 85.6 & 3920 & 1999-2000 & seasonal & TOT & $0.4^{[7]}$ & $0.4(0.2-0.7)$ & 0.4 & 0.4 & 0.5 \\
\hline & Zhuzhang & 28.0 & 99.7 & 3583 & 2004-2005 & monthly & TOR & $0.3^{[11]}$ & $0.3(0.2-0.5)$ & 0.3 & 0.4 & 0.3 \\
\hline
\end{tabular}

a thermal-optical reflectance (TOR), thermal-optical transmittance (TOT), multi-angle absorption photometer (MAAP).

b Values are multi-month averages. References: ${ }^{[1]}$ Beegum et al. (2009), ${ }^{[2]}$ Pathak et al. (2010), ${ }^{[3]}$ Zhang et al. (2008), ${ }^{[4]}$ Nair et al. (2012), ${ }^{[5]}$ Ram et al. (2010b), ${ }^{[6]}$ Ganguly et al. (2009b), ${ }^{[7]}$ Carrico

et al. (2003), ${ }^{[8]}$ Bonasoni et al. (2010), ${ }^{[9]}$ Ram et al. (2010a), ${ }^{[10]}$ Ming et al. (2010), ${ }^{[11]}$ Qu et al. (2008).

${ }^{c}$ Values from Experiment A (Table 5) for 2006. See text for details. Values in parentheses are from the same Experiment but using instead the upper and lower bounds of anthropogenic BC emissions in China and India.

d Values from experiment B (Table 5) for 2006. See text for details.

e Values from experiment C (Table 5) for 2006. See text for details.

${ }^{f}$ Values from experiment D (Table 5) for 2006. See text for details.

accuracy of the heating-gas chromatography system is dominated by the variability of the blank loads of pre-cleaned filters (Xu et al., 2006). The coulometric titration-based analysis measures the acidification of the solution by carbon dioxide produced from $\mathrm{BC}$ combustion in the system (Ming et al., 2009a), where the $\mathrm{pH}$ value of the solution may be interfered by other ions.

\subsubsection{AERONET AAOD}

There are 14 AERONET sites with AAOD retrievals in the Tibetan Plateau and adjacent regions (Table 3 and Fig. 1). These sites are mostly in the Indo-Gangetic Plain, in northern India and along the southern slope of the Himalayas. Following Bond et al. (2013), we infer BC AAOD from monthly averaged aerosol optical depth (AOD) data from AERONET (Version 2.0 Level 2.0 products) for 2006-2012. The monthly means are derived for months when there are 5 or more days with AOD observations. The measurements provide sun and sky radiance observations in the mid-visible range (Dubovik and King, 2000), which allows for inference of aerosol column absorption from retrievals of AOD and single scattering albedo $(\mathrm{SSA})$ via $\mathrm{AAOD}=\mathrm{AOD} \times(1$ - SSA). As pointed out by Bond et al. (2013), the removal of SSA data at low AOD values from the AERONET data (for data quality assurance) likely introduces a positive bias in the AAOD retrieval. Both BC aerosols and dust particles contribute to the absorption. The absorption by fine-mode aerosols is primarily from $\mathrm{BC}$ while the absorption by larger particles (diameter $>1 \mu \mathrm{m}$ ) is principally from dust. Dust AAOD is estimated from the super-micron part of aerosol size distribution provided by the AERONET retrieval method and a refractive index of $1.55+0.0015 \mathrm{i}$ (Bond et al., 2013). BC AAOD is then the difference between the total and dust AAOD. This process attributes all fine-mode aerosol absorption to $\mathrm{BC}$. Because of the contributions from $\mathrm{OC}$ and fine dust particles to fine-mode AAOD, the inferred BC AAOD is likely biased high. Bond et al. (2013) estimated that the uncertainty from the impact of dust and OC on the finemode AAOD could be as large as $40-50 \%$. The limited AERONET sampling in this region is another source of uncertainty (Bond et al., 2013).

\subsubsection{Model description and simulations}

The GEOS-Chem model is driven by assimilated meteorology from the Goddard Earth Observing System (GEOS) of the NASA Global Modeling and Assimilation Office (GMAO). We use here GEOS-Chem version 9-01-03 (available at http://geos-chem.org), driven by GEOS-5 data assimilation system (DAS) meteorological fields. The meteorological fields have a native horizontal resolution of $0.5^{\circ} \times 0.667^{\circ}$, 72 vertical layers, and a temporal resolution of $6 \mathrm{~h}(3 \mathrm{~h}$ for surface variables and mixing depths). The spatial resolution is degraded to $2^{\circ} \times 2.5^{\circ}$ in the horizontal and 47 layers in the vertical (from the surface to $0.01 \mathrm{hPa}$ ) for computational expediency. The lowest model levels are centered at approximately 60, 200, 300, 450, 600, 700, 850, 1000, 1150, 1300, 1450,1600 , and $1800 \mathrm{~m}$ a.s.l.

Tracer advection is computed every 15 minutes with a flux-form semi-Lagrangian method (Lin and Rood, 1996). Tracer moist convection is computed using GEOS 
Table 2. Observed and simulated BC concentrations in snow over the Tibetan Plateau (see also Fig. 1).

\begin{tabular}{|c|c|c|c|c|c|c|c|c|c|c|}
\hline \multirow[t]{2}{*}{ Region } & \multirow[t]{2}{*}{ Site } & \multirow{2}{*}{$\begin{array}{l}\text { Lat. } \\
\left({ }^{\circ} \mathrm{N}\right)\end{array}$} & \multirow{2}{*}{$\begin{array}{l}\text { Long. } \\
\left({ }^{\circ} \mathrm{E}\right)\end{array}$} & \multirow{2}{*}{$\begin{array}{l}\text { Elev. } \\
(\mathrm{km})\end{array}$} & \multirow[t]{2}{*}{ Time } & \multicolumn{5}{|c|}{$\mathrm{BC}$ in snow $\left(\mu \mathrm{g} \mathrm{kg}^{-1}\right)$} \\
\hline & & & & & & Obs. $^{\mathrm{a}}$ & Exp. $A^{b}$ & Exp. $B^{c}$ & Exp. $C^{d}$ & Exp. $D^{\mathrm{e}}$ \\
\hline \multirow[t]{12}{*}{ The Himalayas } & Zuoqiupu & 29.21 & 96.92 & 5.50 & monsoon 2006 & $7.9^{[2]}$ & $22.5(13.6-43.0)$ & 18.4 & 25.5 & 24.6 \\
\hline & & 29.21 & 96.92 & 5.60 & non-monsoon 2006 & $15.9^{[2]}$ & $21.2(13.6-36.9)$ & 18.3 & 31.9 & 53.9 \\
\hline & Qiangyong & 28.83 & 90.25 & 5.40 & summer 2001 & $43.1^{[1]}$ & $66.1(42.2-122.8)$ & 49.7 & 63.7 & 18.3 \\
\hline & Noijin Kangsang & 29.04 & 90.20 & 5.95 & annual 2005 & $30.6^{[2]}$ & $39.5(21.1-60.8)$ & 34.6 & 52.3 & 22.5 \\
\hline & East Rongbuk & 28.02 & 86.96 & 6.50 & monsoon 2001 & $35.0^{[3]}$ & $26.4(16.8-48.9)$ & 22.7 & 29.2 & 22.4 \\
\hline & & 28.02 & 86.96 & 6.50 & non-monsoon 2001 & $21.0^{[3]}$ & $32.8(21.6-55.6)$ & 31.1 & 59.4 & 42.7 \\
\hline & & 28.02 & 86.96 & 6.50 & summer 2002 & $20.3^{[4]}$ & $26.5(16.8-49.3)$ & 22.8 & 28.9 & 23.0 \\
\hline & & 28.02 & 86.96 & 6.50 & Oct. 2004 & $18.0^{[4]}$ & $20.5(13.6-35.6)$ & 20.8 & 26.0 & 25.4 \\
\hline & & 28.02 & 86.96 & 6.50 & Sept. 2006 & $9.0^{[7]}$ & $26.0(16.7-47.6)$ & 22.4 & 30.0 & 20.6 \\
\hline & & 28.02 & 86.96 & 6.52 & May 2007 & $41.8^{[6]}$ & $27.1(16.9-41.7)$ & 24.7 & 29.7 & 45.2 \\
\hline & Kangwure & 28.47 & 85.82 & 6.00 & summer 2001 & $21.8^{[1]}$ & $26.5(16.8-49.3)$ & 22.8 & 28.9 & 18.0 \\
\hline & Namunani & 30.45 & 81.27 & 5.90 & summer 2004 & $4.3^{[1]}$ & $24.8(15.8-45.2)$ & 21.2 & 26.6 & 19.6 \\
\hline \multirow{2}{*}{$\begin{array}{l}\text { Northwestern } \\
\text { Tibetan Plateau }\end{array}$} & Mt. Muztagh & 38.28 & 75.02 & 6.35 & summer 2001 & $37.2^{[1]}$ & $31.0(23.3-52.8)$ & 36.6 & 31.9 & 32.9 \\
\hline & & 38.28 & 75.10 & 6.30 & 1999 & $26.6^{[1]}$ & $33.0(26.6-48.6)$ & 36.4 & 45.8 & 42.1 \\
\hline \multirow{3}{*}{$\begin{array}{l}\text { Northeastern } \\
\text { Tibetan Plateau }\end{array}$} & Laohugou \#12 & 39.43 & 96.56 & 5.05 & Oct. 2005 & $35.0^{[4]}$ & $54.4(34.9-97.2)$ & 60.0 & 60.3 & 65.0 \\
\hline & Qiyi & 39.23 & 97.06 & 4.85 & Jul. 2005 & $22.0^{[4]}$ & $25.7(18.5-67.0)$ & 30.3 & 27.4 & 48.9 \\
\hline & 1 July glacier & 39.23 & 97.75 & 4.60 & summer 2001 & $52.6^{[1]}$ & $59.2(32.8-122.8)$ & 68.8 & 61.0 & 106.2 \\
\hline \multirow{7}{*}{$\begin{array}{l}\text { Central } \\
\text { Tibetan Plateau }\end{array}$} & Meikuang & 35.67 & 94.18 & 5.20 & summer 2001 & $446^{[1]}$ & $24.4(15.4-47.0)$ & 24.8 & 27.2 & 32.9 \\
\hline & & 35.67 & 94.18 & 5.20 & Nov. 2005 & $81.0^{[5]}$ & $40.9(18.8-50.0)$ & 43.3 & 50.5 & 38.6 \\
\hline & Tanggula & 33.11 & 92.09 & 5.80 & 2003 & $53.1^{[2]}$ & $16.1(10.4-28.6)$ & 14.5 & 25.6 & 12.0 \\
\hline & Dongkemadi & 33.10 & 92.08 & 5.60 & summer 2001 & $18.2^{[1]}$ & $19.6(12.2-36.8)$ & 17.7 & 22.1 & 15.0 \\
\hline & & 33.10 & 92.08 & 5.60 & year 2005 & $36.0^{[7]}$ & $15.8(10.2-28.1)$ & 14.2 & 23.7 & 11.8 \\
\hline & La'nong & 30.42 & 90.57 & 5.85 & Jun. 2005 & $67.0^{[4]}$ & $39.1(25.8-72.9)$ & 35.9 & 37.8 & 22.9 \\
\hline & Zhadang & 30.47 & 90.50 & 5.80 & Jul. 2006 & $87.4^{[4]}$ & $27.9(17.0-53.4)$ & 21.7 & 30.3 & 19.3 \\
\hline \multirow{3}{*}{$\begin{array}{l}\text { North of } \\
\text { the plateau }\end{array}$} & Haxilegen River & 43.73 & 84.46 & 3.76 & Oct. 2006 & $46.9^{[4]}$ & $36.1(34.1-45.2)$ & 37.9 & 36.7 & 71.4 \\
\hline & Urumqi Riverhead & 43.10 & 86.82 & 4.05 & Nov. 2006 & $141^{[5]}$ & $131.9(71.8-270.4)$ & 155.2 & 118.4 & 127.9 \\
\hline & Miao'ergou \#3 & 43.06 & 94.32 & 4.51 & Aug. 2005 & $111^{[4]}$ & $98.8(59.3-158.2)$ & 113.2 & 103.7 & 113.8 \\
\hline
\end{tabular}

${ }^{a}$ References: ${ }^{[1]}$ Xu et al. (2006), ${ }^{[2]}$ Xu et al. (2009), ${ }^{[3]}$ Ming et al. (2008), ${ }^{[4]}$ Ming et al. (2009a), ${ }^{[5]}$ Ming et al. (2009b), ${ }^{[6]}$ Ming et al. (2012), ${ }^{[7]}$ Ming et al. (2013).

b Values from Experiment A (Table 5) for 2006. See text for details. Values in parentheses are from the same Experiment but using instead the upper and lower bounds of anthropogenic BC emissions in China and India.

c Values from experiment B (Table 5) for 2006. See text for details.

$\mathrm{d}$ Values from experiment $\mathrm{C}$ (Table 5) for 2006. See text for details.

e Values from experiment D (Table 5) for 2006. See text for details.

convective, entrainment, and detrainment mass fluxes as described by Allen et al. (1996a, b). The deep convection in GEOS-5 is parameterized using the relaxed ArakawaSchubert scheme (Arakawa and Schubert, 1974; Moorthi and Suarez, 1992), and the shallow convection treatment follows Hack (1994). Park et al. (2003, 2006) first described GEOSChem simulation of carbonaceous aerosols.

\subsubsection{BC emissions}

The global anthropogenic $\mathrm{BC}$ emissions are from Bond et al. (2007), with an annual emission of $4.4 \mathrm{Tg} C$ for the year 2000. Anthropogenic BC emissions in Asia, chiefly in China and India, have increased significantly since 2000 (Granier et al., 2011). Zhang et al. (2009) developed an Asian anthropogenic BC emissions (for China and India and the rest of Asia) for 2006 for the Intercontinental Chemical Transport Experiment-B (INTEX-B) field campaign (Singh et al., 2009), with considerable updates to a previous inventory de- veloped by Streets et al. (2003). They employed a dynamic methodology that accounts for rapid technology renewal and updated the fuel consumption data. Fu et al. (2012) pointed out that Zhang et al. (2009) underestimate anthropogenic BC emissions in China by a factor of 1.6 compared with the topdown estimates. Lu et al. (2011) further updated the activity rates, technology penetration data and emission factors in China and India, and reported anthropogenic BC emissions only in these two countries for 1996-2010. Table 4 is a summary of the two inventories. Anthropogenic BC emissions in India are lower in the Zhang et al. (2009) inventory (hereinafter the INTEX-B inventory) than in the Lu et al. (2011) inventory (hereinafter the LU inventory) by a factor of 2 , while emissions in China are $10 \%$ higher in the INTEX-B inventory than in the LU inventory (Table 4). The higher emissions in India in the LU inventory are primarily a result of the updated biofuel emission factors and the new method used to estimate biofuel consumptions. The biofuel emissions, which 
Table 3. Observed and simulated annual mean BC AAOD at AERONET sites over the Tibetan Plateau (see also Fig. 1).

\begin{tabular}{|c|c|c|c|c|c|c|c|c|}
\hline \multirow[t]{2}{*}{ Region } & \multirow[t]{2}{*}{ Site } & \multirow{2}{*}{$\begin{array}{l}\text { Lat. } \\
\left({ }^{\circ} \mathrm{N}\right)\end{array}$} & \multirow{2}{*}{$\begin{array}{l}\text { Long. } \\
\left({ }^{\circ} \mathrm{E}\right)\end{array}$} & \multirow{2}{*}{$\begin{array}{l}\text { Alt. } \\
(\mathrm{m})\end{array}$} & \multirow[t]{2}{*}{ Time } & \multicolumn{3}{|c|}{ BC AAOD } \\
\hline & & & & & & Obs. $^{\text {a }}$ & Model $^{\mathrm{b}}$ & Ratio $^{c}$ \\
\hline \multirow[t]{5}{*}{ The Indo-Gangetic Plain } & Lahore & 31.54 & 74.33 & 270 & $2007-2012$ & 0.0434 & $\begin{array}{l}0.0162 \\
(0.0125-0.0239)\end{array}$ & 2.7 \\
\hline & Kanpur & 26.51 & 80.23 & 123 & 2006-2012 & 0.0426 & $\begin{array}{l}0.0221 \\
(0.0071-0.0413)\end{array}$ & 1.9 \\
\hline & Gandhi College & 25.87 & 84.13 & 60 & 2006-2012 & 0.0443 & $\begin{array}{l}0.0282 \\
(0.0179-0.0517)\end{array}$ & 1.6 \\
\hline & Gual_Pahari & 28.43 & 77.15 & 384 & 2008-2010 & 0.0511 & $\begin{array}{l}0.0222 \\
(0.0147-0.0382)\end{array}$ & 2.3 \\
\hline & Jaipur & 26.91 & 75.81 & 450 & 2009-2012 & 0.0202 & $\begin{array}{l}0.0168 \\
(0.0110-0.0296)\end{array}$ & 1.2 \\
\hline \multirow[t]{5}{*}{ The Himalayas } & Jomsom & 28.78 & 83.71 & 2803 & 2012 & 0.0231 & $\begin{array}{l}0.0136 \\
(0.0092-0.0228)\end{array}$ & 1.7 \\
\hline & Pantnagar & 29.05 & 79.52 & 241 & 2008-2009 & 0.0507 & $\begin{array}{l}0.0114 \\
(0.0079-0.0193)\end{array}$ & 4.4 \\
\hline & Nainital & 29.36 & 79.46 & 1939 & 2008-2010 & 0.0204 & $\begin{array}{l}0.0125 \\
(0.0086-0.0212)\end{array}$ & 1.6 \\
\hline & Pokhara & 28.15 & 83.97 & 807 & 2010-2012 & 0.0524 & $\begin{array}{l}0.0056 \\
(0.0037-0.0097)\end{array}$ & 9.4 \\
\hline & Kathmandu Univ. & 27.60 & 85.54 & 1510 & 2009-2010 & 0.0406 & $\begin{array}{l}0.0057 \\
(0.0038-0.0099)\end{array}$ & 7.1 \\
\hline Northeastern Tibetan Plateau & SACOL & 35.95 & 104.14 & 1965 & $2007-2011$ & 0.0163 & $\begin{array}{l}0.0100 \\
(0.0056-0.0204)\end{array}$ & 1.6 \\
\hline Northeast of the Tibetan Plateau & Dalanzadgad & 43.58 & 104.42 & 1470 & 2006, 2012 & 0.0038 & $\begin{array}{l}0.0025 \\
(0.0020-0.0041)\end{array}$ & 1.5 \\
\hline \multirow[t]{2}{*}{ Northwest of the Tibetan Plateau } & Issyk-Kul & 42.62 & 76.98 & 1650 & 2008-2010 & 0.0196 & $\begin{array}{l}0.0020 \\
(0.0017-0.0029)\end{array}$ & 9.8 \\
\hline & Dushanbe & 38.55 & 68.86 & 821 & 2011-2012 & 0.0131 & $\begin{array}{l}0.0030 \\
(0.0027-0.0035)\end{array}$ & 4.4 \\
\hline
\end{tabular}

a AERONET retrieved BC AAOD (Bond et al., 2013). Values are multi-year averages.

${ }^{b}$ Values from Experiment A (Table 5) for 2006. See text for details. Values in parentheses are from the same experiment but use the upper and lower bounds of anthropogenic BC emissions in China and India instead.

${ }^{c}$ The ratio of AERONET retrieved to GEOS-Chem modeled BC AAOD

Table 4. Anthropogenic BC emissions in China and India in 2006.

\begin{tabular}{lllll}
\hline & \multicolumn{2}{c}{ China } & \multicolumn{2}{c}{ India } \\
Emissions $\left(\mathrm{Gg} \mathrm{yr}^{-1}\right)$ & Lu et al. (2011) & Zhang et al. (2009) & Lu et al. (2011) & Zhang et al. (2009) \\
\hline Industry & 509 & 575 & 201 & 47 \\
Power plants & 15 & 36 & 1 & 8 \\
Residential & 971 & 1022 & 608 & 268 \\
Transportation & 178 & 205 & 75 & 80 \\
\hline Total & $1673\left(954-3229^{*}\right)$ & $1838(884-3823)$ & $885(522-1655)$ & $404(112-1454)$ \\
\hline
\end{tabular}

* Uncertainties (in parentheses). 
are dominated by residential burning, account for more than $50 \%$ of total BC emissions in India (Lu et al., 2011). There are large uncertainties in both inventories. Lu et al. (2011) used a Monte Carlo method to show that the $95 \%$ uncertainty ranges of $\mathrm{BC}$ emissions are from -43 to $93 \%$ for China and from -41 to $87 \%$ for India. The uncertainties in the INTEX-B inventory are $\pm 208 \%$ for China and $\pm 360 \%$ for India (Zhang et al., 2009). A recent study by Qin and Xie (2012) showed slightly (5-10\%) lower total anthropogenic BC emissions in China than those from Lu et al. (2011) for 2006, but the emissions in the northeastern and northwestern China were higher by a factor of 2. Kurokawa et al. (2013) further updated $\mathrm{BC}$ emissions in Asia and found $10 \%$ lower anthropogenic BC emissions for China and $30 \%$ lower for India compared with those from Lu et al. (2011), yet with a similar spatial distribution. Wang et al. (2014) developed a new global BC emission inventory, where anthropogenic $\mathrm{BC}$ emissions are $20 \%$ higher in China and $30 \%$ lower in India than those from Lu et al. (2011). They found that the use of the new inventory reduces model biases of surface BC concentrations in Asia by 15-20\%. However, the abovementioned three latest inventories are still associated with large uncertainties (95\% confidence intervals), which are more than $100 \%$ for anthropogenic BC emissions in China and India (Qin and Xie, 2012; Kurokawa et al., 2013; Wang et al., 2014).

Global biomass burning emissions are from the Global Fire Emissions Database version 3 (GFEDv3) (van der Werf et al., 2010). Kaiser et al. (2012) showed that GFEDv3 underestimates carbon emissions by a factor of 2-4 globally because of undetected small fires. Randerson et al. (2012) reported an updated GFEDv3 inventory that accounts for small fire emissions. Small fires increase carbon emissions by $50 \%$ in southeast Asia and equatorial Asia (Randerson et al., 2012). We use the GFEDv3 emissions with a monthly temporal resolution in the present study. The uncertainty of the GFEDv3 emissions is at least $20 \%$ globally and higher in boreal regions and equatorial Asia (van der Werf et al., 2010). The major uncertainty lies in insufficient data on burned area, fuel load and emission factor (van der Werf et al., 2010; Randerson et al., 2012).

\subsubsection{BC deposition}

Simulation of aerosol dry and wet deposition follows Liu et al. (2001). Dry deposition of aerosols uses a resistance-inseries model (Walcek et al., 1986) dependent on local surface type and meteorological conditions. There have since been many updates. A standard resistance-in-series scheme (Wesely, 1989) has been implemented in the non-snow/non-ice regions (Wang et al., 1998) with a constant aerosol dry deposition velocity of $0.03 \mathrm{~cm} \mathrm{~s}^{-1}$ prescribed over snow and ice (Wang et al., 2011). This velocity is within the range $(0.01-$ $0.07 \mathrm{~cm} \mathrm{~s}^{-1}$ ) employed in Liu et al. (2011) to improve the BC simulation in the Geophysical Fluid Dynamics Laboratory
(GFDL) Atmospheric Model version 3 (AM3) global model (Donner et al., 2011). We found that dry deposition accounts for $20 \%$ of the total BC deposition over the Tibetan Plateau in winter and $10 \%$ in summer.

Liu et al. (2001) described the wet scavenging scheme for aerosols in the GEOS-Chem. Wang et al. (2011) implemented in the model a new below-cloud scavenging parameterization for individual aerosol mode, which distinguishes between the removal by snow and by rain drops for aerosol washout. They also applied different in-cloud scavenging schemes to cold and to warm clouds, and with an improved areal fraction of a model grid box that experiences precipitation. These changes are included in the GEOS-Chem version used for the present study.

The GEOS-Chem model does not directly predict BC (or any aerosols for that matter) in snow at the surface in the absence of a land-surface model that explicitly treats snow including its aging. As an approximation, we estimate BC concentration in snow in the model as the ratio of total $\mathrm{BC}$ deposition to total precipitation, following Kopacz et al. (2011) and Wang et al. (2011). Although the use of total precipitation here is reasonable considering the low temperature typical over the Tibetan Plateau (Wu and Liu, 2004), it introduces uncertainties to the calculation of snow BC concentration. Bonasoni et al. (2010) found that precipitation can be partly in the form of rain even at altitudes of $5 \mathrm{~km}$ in the Himalayas. Thus, the use of total precipitation may overestimate both snow precipitation and $\mathrm{BC}$ removed by snow. Besides, rain also results in the melting of snowpack (Marks et al., 2001), which further affects BC concentration in snow. Additional uncertainties exist in the GEOS-5 precipitation fields because of the coarse model resolution and the complex topography in the plateau (see Sect. 3.2). Ménégoz et al. (2013) showed that using a higher resolution model $\left(0.2^{\circ} \times 0.2^{\circ}\right)$ improves the simulation of the spatial variability of precipitation in the Himalayas, but the bias in total precipitation remains high. The uncertainty in precipitation is thus propagated to the $\mathrm{BC}$ concentration in snow computed from model results. Our calculation of $\mathrm{BC}$ concentration in snow assumes a well mixing of BC and snow. However, BC content is not uniform throughout a snow column. Thus, an ideal comparison of modeled and observed BC concentrations in snow should be for the same depth of a snow column. We also neglect the aging of surface snow and the internal mixing of snow and $\mathrm{BC}$, which conceivably contribute to the underestimate of $\mathrm{BC}$ concentration in snow computed here. This may be an especially important issue for comparisons in the central plateau and to the north of the plateau, where snowmelt has been suggested to strongly increase BC concentration in snow (Zhou et al., 2007; Ming et al., 2013). 


\subsubsection{BC aging}

Freshly emitted BC is mostly (80\%) hydrophobic (Cooke et al., 1999). Hydrophobic BC becomes hydrophilic typically on the timescale of a few days (McMeeking et al., 2011, and references therein) because of coating by soluble materials like sulfate and organic matter (Friedman et al., 2009; Khalizov et al., 2009). The internal mixing of BC and other aerosol constituents significantly changes the morphology, hygroscopicity and optical properties of BC particles (Zhang et al., 2008). This further influences BC absorption efficiency (Bond et al., 2006) and lifetime against deposition (Mikhailov et al., 2001). However, the aging process is not explicitly simulated in the GEOS-Chem, where an e-folding time of 1.15 days for the conversion of hydrophobic to hydrophilic BC is simply assumed (Park et al., 2005; Kopacz et al., 2011; Wang et al., 2011). Liu et al. (2011) proposed a condensation-coagulation parameterization for BC aging where the conversion time is not uniform but varies. Specifically, the conversion is assumed to be primarily a result of sulfuric acid deposition (condensation) onto BC particles, and the mass deposition rate is proportional to the concentration of gaseous sulfuric acid and to the BC particle surface area. Gaseous atmospheric sulfuric acid is a product of sulfur dioxide oxidation by the hydroxyl radical $(\mathrm{OH})$. Consequently its steady-state concentration is linearly linked to $\mathrm{OH}$ concentration. Thus, in the absence of nucleation, which is a slow process when there exists plenty of primary particles as found in urban and biomass burning plumes (Seinfeld and Pandis, 2006), the BC aging rate can be parameterized as a linear function of $\mathrm{OH}$ concentration, where the coefficient of $\mathrm{OH}$ concentration controls a fast aging process (i.e., condensation) and the constant term governs a slow aging process (e.g., coagulation). Huang et al. (2013) further combined the Liu et al. (2011) parameterization with a chemical oxidation aging mechanism from chamber study results (Poschl et al., 2001) in GEOS-Chem. They found that the chemical aging effects on surface BC concentrations are strongest in the tropical regions but negligible over the Tibetan Plateau.

\subsubsection{Model simulations}

For the present study, we conducted four GEOS-Chem simulations for 2006 (Table 5). Detailed discussions and justifications for these model experiments are provided below where appropriate. Model results are sampled at the corresponding locations of the measurement sites. Model results presented here are monthly averages. As pointed out in previous studies (Fairlie et al., 2007; Mao et al., 2011), comparing localized observations with model results that are representative of a much larger area is inherently problematic. The mountainous sites and the complex terrain in the Tibetan Plateau further complicate the comparison.
In Experiment A, we replace the Bond et al. (2007) emissions in China and India with the LU inventory and use the INTEX-B inventory for the rest of Asia. This is our standard simulation, and the results are used for all model evaluations presented here unless stated otherwise. We also provide the model results from Experiment A but instead using the lower and upper bounds of anthropogenic BC emissions from China and India estimated by Lu et al. (2011). We find that wet deposition accounts for $83 \%$ of the global annual $\mathrm{BC}$ deposition, consistent with the previous results of $78.6 \pm 17 \%$ from the Aerosol inter-Comparison project (AeroCom) multi-model study (Textor et al., 2006). The tropospheric lifetime of $\mathrm{BC}$ against deposition is 5.5 days, at the lower end of the range (5-11 days) reported by Koch et al. (2009). The difference between Experiments B and A is that we replace the Bond et al. (2007) emissions in China and India with the INTEX-B inventory in Experiment B. By contrasting model results from these two experiments, we aim to assess the sensitivity of BC in the Tibetan Plateau to changes in the anthropogenic emissions from India and China, the two largest source regions of BC to the plateau (Kopacz et al., 2011; Lu et al., 2012), as will be discussed in further details in Sect. 4. Both Experiments A and B use an e-folding time of 1.15 days for $\mathrm{BC}$ aging. Experiment $\mathrm{C}$ applies the Liu et al. (2011) parameterization for BC aging instead. We used monthly mean $\mathrm{OH}$ concentrations with diurnal variations in the parameterization, which is derived from the offline GEOS-chem simulation with the same spatial resolution as BC simulations. The resulting e-folding time is 2.5 days on average globally and 2 days in Asia. The longer e-folding time results in longer atmospheric lifetime, larger deposition and higher hydrophobic fraction of BC over the Tibetan Plateau (not shown). We discuss further in Sect. 5 the differing results between Experiments $\mathrm{C}$ and $\mathrm{A}$, which allow us to appraise the effect of a variable $\mathrm{BC}$ aging time on $\mathrm{BC}$ in the plateau. In Experiment $\mathrm{D}$, we replace the model resolution of $2^{\circ} \times 2.5^{\circ}$ used in Experiment $A$ with a finer resolution of $0.5^{\circ} \times 0.667^{\circ}$ nested over Asia $\left(11^{\circ} \mathrm{S}-55^{\circ} \mathrm{N}\right.$, $\left.70-150^{\circ} \mathrm{E}\right)$. The differences between the results from Experiments D and A will be discussed in Sect. 6 for the purpose of evaluating the impact of model resolution on $\mathrm{BC}$ in the plateau. In all model experiments, we use a BC mass absorption cross section (MAC) of $7 \mathrm{~m}^{2} \mathrm{~g}^{-1}$ from observations (Clarke et al., 2004) for calculating modeled BC AAOD. We note that BC MAC is associated with large uncertainties, which varies from 3 to $25 \mathrm{~m}^{2} \mathrm{~g}^{-1}$ depending on atmospheric conditions (Bond and Bergstrom, 2006). 
Table 5. GEOS-Chem simulations of BC.

\begin{tabular}{|c|c|c|c|c|c|}
\hline \multicolumn{2}{|c|}{ Model experiment } & A & $\mathrm{B}$ & $\mathrm{C}$ & $\mathrm{D}$ \\
\hline \multicolumn{2}{|l|}{ Resolution } & $2^{\circ} \times 2.5^{\circ}$ & $2^{\circ} \times 2.5^{\circ}$ & $2^{\circ} \times 2.5^{\circ}$ & $\begin{array}{l}0.5^{\circ} \times 0.667^{\circ}(\text { Asia }) \\
2^{\circ} \times 2.5^{\circ}(\text { global })\end{array}$ \\
\hline $\begin{array}{l}\text { Anthropogenic } \\
\text { emissions }\end{array}$ & $\begin{array}{l}\text { China \& India } \\
\text { Rest of Asia } \\
\text { Rest of world }\end{array}$ & \multicolumn{4}{|c|}{$\begin{array}{c}\text { Zhang et al. (2009) } \\
\text { Bond et al. (2007) }\end{array}$} \\
\hline \multicolumn{2}{|c|}{ Biomass burning emissions } & \multicolumn{4}{|c|}{ GFEDv3 (van der Werf et al., 2010), with updates from Randerson et al. (2012) } \\
\hline \multicolumn{2}{|c|}{$\begin{array}{c}\text { BC aging } \\
\text { (hydrophobic to hydrophilic) }\end{array}$} & $\begin{array}{l}\text { e-folding time } \\
1.15 \text { days }\end{array}$ & $\begin{array}{l}\text { e-folding time } \\
1.15 \text { days }\end{array}$ & Liu et al. (2011) & $\begin{array}{l}\text { e-folding time } \\
1.15 \text { days }\end{array}$ \\
\hline Deposition & $\begin{array}{l}\text { Dry deposition } \\
\text { Wet deposition }\end{array}$ & \multicolumn{4}{|c|}{$\begin{array}{l}\text { Wesely (1989) as implemented by Wang et al. (1998) } \\
\text { Liu et al. (2001) with updates from Wang et al. (2011) }\end{array}$} \\
\hline
\end{tabular}
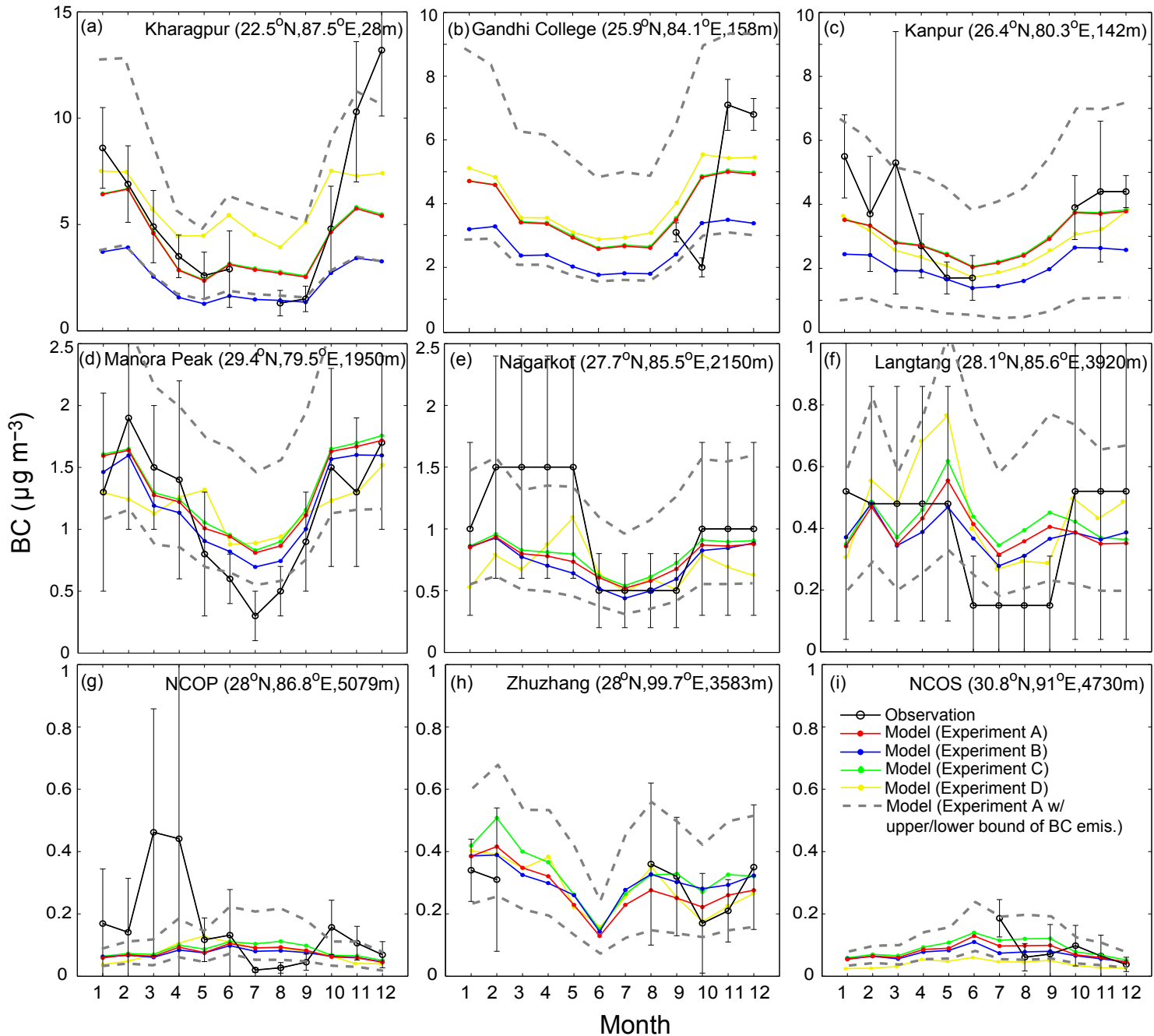

Figure 2. Observed (black curve) and GEOS-Chem simulated (colored curves: red - Experiment A; blue - Experiment B; green - Experiment C; yellow - Experiment D; grey dashed curves - Experiment A using upper/lower bounds of anthropogenic BC emissions in China and India) monthly mean surface-BC concentration $\left(\mu \mathrm{g} \mathrm{m}^{-3}\right)$ at three rural sites $(\mathbf{a}-\mathbf{c})$ and six remote sites (d-i) over the Tibetan Plateau in 2006 (see Table 1 and Fig. 1). Only seasonal mean observations are available at sites e and f. Also shown are standard deviations for observations (error bars). See text for details. 


\section{Results}

\subsection{BC in surface air}

Figure 2 shows surface $\mathrm{BC}$ concentrations at three rural sites: Kharagpur $\left(22.5^{\circ} \mathrm{N}, 87.5^{\circ} \mathrm{E}\right.$; $28 \mathrm{~m}$ a.s.l.; Fig. 2a), Gandhi College $\left(25.9^{\circ} \mathrm{N}, 84.1^{\circ} \mathrm{E}\right.$; $158 \mathrm{~m}$ a.s.l.; Fig. $\left.2 \mathrm{~b}\right)$ and Kanpur $\left(26.4^{\circ} \mathrm{N}, 80.3^{\circ} \mathrm{E} ; 142 \mathrm{~m}\right.$ a.s.l.; Fig. $\left.2 \mathrm{c}\right)$. Model results reproduce the observed $\mathrm{BC}$ concentrations with the exception of winter, when the model underestimates the concentrations by $50 \%$. The high wintertime concentrations are primarily because of emissions from agricultural waste and wood fuel burning that is dominant over the Indo-Gangetic Plain during winter (Ram et al., 2010b). Model results using the upper bound of BC emissions capture the observed high concentrations in winter (Fig. 2a-c). The wintertime low biases in the model therefore clearly call for enhanced emission estimates. Moorthy et al. (2013) found that modeled surface-BC concentrations in this region are underestimated by more than a factor of 2 during winter when the planetary boundary layer (PBL) is convectively stable, while model underestimates are smaller in summer when the PBL is unstable. They suggested that the overestimate of wintertime PBL height in chemical transport models is an important contributor to model underestimates of surface pollutant concentrations. Lin and McElory (2010) pointed out that the assumption of full PBL mixing (instantaneous vertical mixing throughout the mixing depth) in the GEOS-Chem tends to overestimate vertical mixing under a stable PBL condition. They proposed and implemented in GEOS-Chem a non-local PBL mixing scheme (Holtslag and Boville, 1993; Lin et al., 2008), where the mixing states are determined by static instability. They used a local K-theory scheme (Louis, 1979) for a stable PBL and added a "non-local" term for an unstable PBL to account for the PBL-wide mixing triggered by large eddies. Our results show that the non-local boundary layer mixing increases surface $\mathrm{BC}$ concentrations by up to $25 \%$ in winter and spring, a significant improvement. Nair et al. (2012) showed that the non-local boundary layer mixing still tends to overestimate the vertical mixing during winter in the Indo-Gangetic Plain.

Model results are within $\pm 50 \%$ of the observations at two remote sites, Zhuzhang $\left(28.0^{\circ} \mathrm{N}, 99.7^{\circ} \mathrm{E} ; 3583 \mathrm{~m}\right.$ a.s.l.; Fig. 2h) and NCOS (30.8 N, $91.0^{\circ}$ E; 4730 m a.s.l.; Fig. 2 i), where observations are available for only fall and winter. Model results are lower than the observations at NCOP $\left(28.0^{\circ} \mathrm{N}, 86.8^{\circ} \mathrm{E}\right.$; $5079 \mathrm{~m}$ a.s.l.; Fig. $\left.2 \mathrm{~g}\right)$ and Nagarkot $\left(27.7^{\circ} \mathrm{N}, 85.5^{\circ} \mathrm{E} ; 2150 \mathrm{~m}\right.$ a.s.l.; Fig. $\left.2 \mathrm{e}\right)$ by a factor of 2 in spring. Using the upper bound of $\mathrm{BC}$ emissions captures the springtime high concentrations at Nagarkot but not at NCOP (Fig. 2g, e). The two sites are influenced by emissions from nearby Nepal valleys transported by the mountain-valley wind (Carrico et al., 2003; Bonasoni et al., 2010). In contrast, model results capture the relatively high concentrations in winter and spring observed at Manora Peak $\left(29.4^{\circ}, 79.5^{\circ} \mathrm{E}\right.$; $1950 \mathrm{~m}$ a.s.l.; Fig. 2d) and Langtang

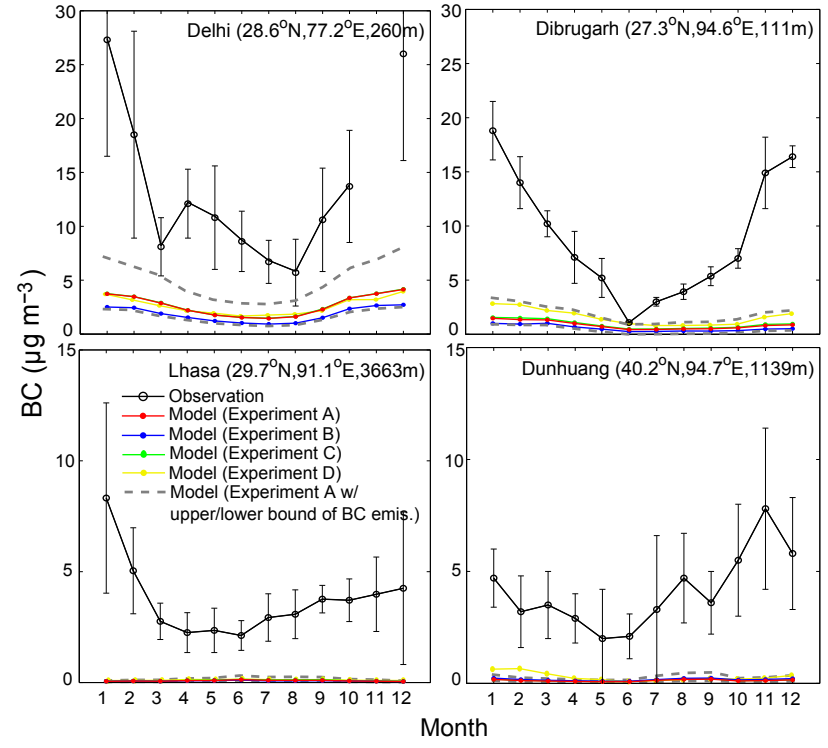

Figure 3. Same as Fig. 2, but for four urban sites (see Table 1 and Fig. 1).

$\left(28.1^{\circ} \mathrm{N}, 85.6^{\circ} \mathrm{E} ; 3920 \mathrm{~m}\right.$ a.s.l.; Fig. $\left.2 \mathrm{f}\right)$, but overestimate the summertime concentrations by a factor of 2 . Using the lower bound of $\mathrm{BC}$ emissions is still not able to capture the observed low values in summer (Fig. 2d, f). Part of the discrepancies is explained by the inherent difficulty in simulating the meteorological fields over the complex Himalayan terrain. Chen et al. (2009) showed that the terrain effects and meteorological features in the Tibetan Plateau are not entirely reproduced by the GEOS- 5 meteorological fields. Such difficulty is not unique to the Himalaya region. Emery et al. (2012) also showed that the transport of chemical species is not well simulated over the complex terrain in the western US using GEOS-Chem driven by GEOS-5 meteorological fields $2^{\circ} \times 2.5^{\circ}$.

Surface concentrations of BC at Lhasa and Delhi, two urban sites (see Table 1), are strongly affected by emissions from city traffic and industries (Zhang et al., 2008; Beegum et al., 2009). The BC concentrations at Dibrugarh are highly impacted by the emissions from the oil wells upwind and vehicular emissions from national highways nearby (Pathak et al., 2010). The concentrations at Dunhuang, a well-known tourist attraction and archaeological site, likely reflect vehicular emissions associated with tourist traffic including tour buses. All four sites are characterized by strong local emissions. Model results reproduce the seasonal trends at these "urban" sites (sites that are near urban centers or heavily influenced by local emissions), but are low by an order of magnitude (Fig. 3). Using the upper bound of BC emissions results in doubling $\mathrm{BC}$ concentrations (Table 1), which by itself still cannot fully explain the model versus observation discrepancies. We exclude these four urban sites from analysis hereinafter. 

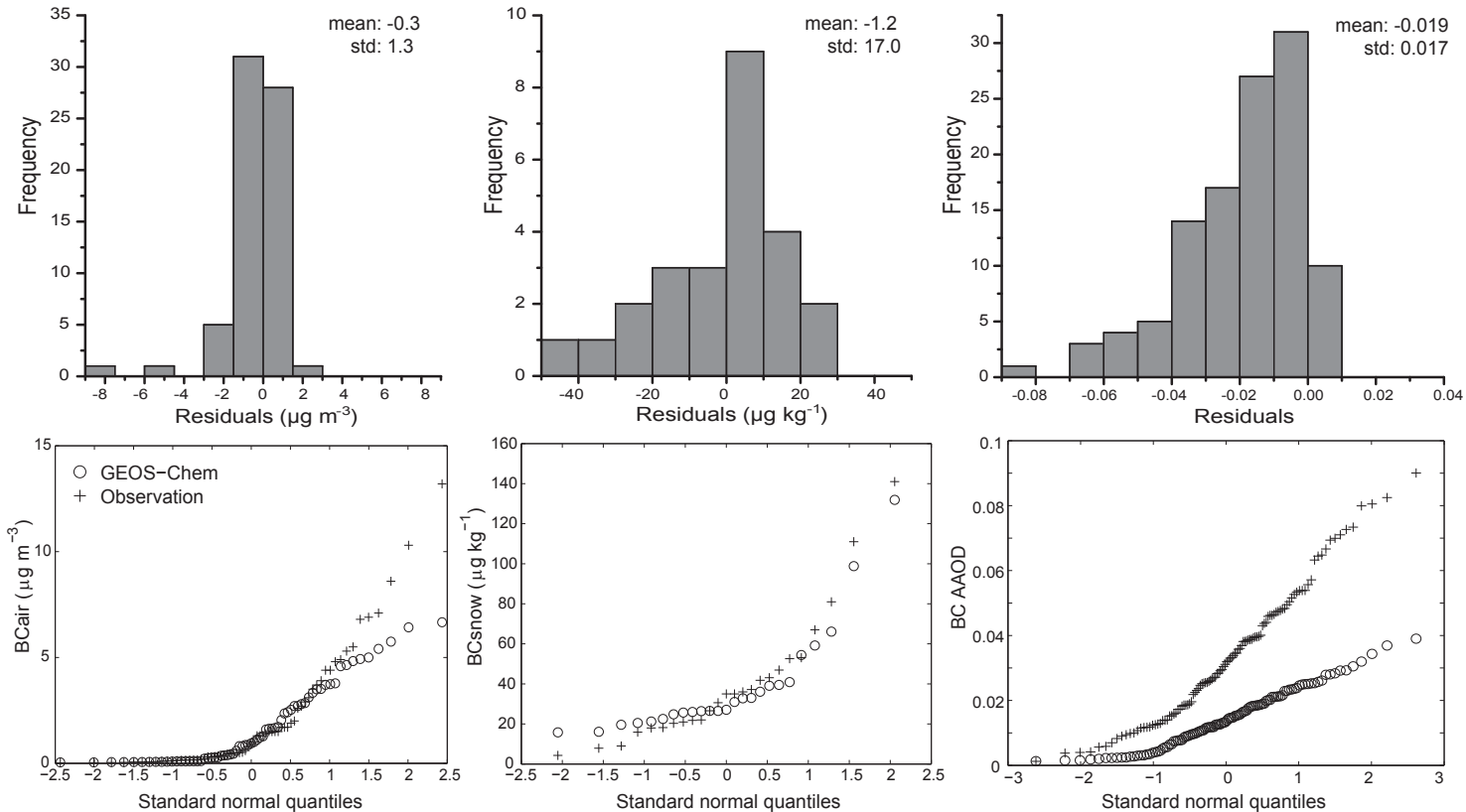

Figure 4. Frequency histogram of residual errors (model-observation) (top row) and cumulative probability distributions (bottom row) for surface BC (left column), BC in snow (middle column), and BC AAOD (right column) at sites in and around the Tibetan Plateau (see Tables 1,2 and 3 and Fig. 1). Also shown are the mean and standard deviation of residual errors. Values are for 2006 unless stated otherwise. See text for details.

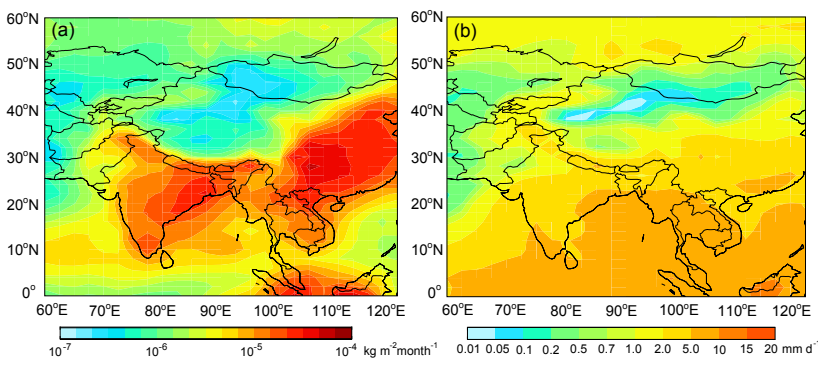

Figure 5. (a) GEOS-Chem simulated annual mean total BC deposition $\left(\mathrm{kg} \mathrm{m}^{-2}\right.$ month $\left.^{-1}\right)$ over Asia and (b) GEOS-5 annual mean total precipitation $\left(\mathrm{mm} \mathrm{day}^{-1}\right)$ over Asia. Values are for 2006.

There is a small negative bias of $-0.3 \mu \mathrm{g} \mathrm{m}^{-3}$ in modelsimulated surface-BC concentrations (Fig. 4, left column), and the difference between model results and the observations is statistically insignificant. We note that the residual errors at very low $\mathrm{BC}$ concentrations may not be particularly meaningful. Overall, model results reproduce the spatiotemporal variation of surface BC concentration throughout the Tibetan Plateau ( $r=0.9$, root-mean-square error $(\mathrm{RMSE})=1.3 \mu \mathrm{g} \mathrm{m}^{-3}$ ) with the exception of peak values (Fig. 4).

\section{2 $\quad B C$ in snow}

$\mathrm{BC}$ deposition and precipitation together determine $\mathrm{BC}$ concentration in snow, which we approximate as the ratio of total $\mathrm{BC}$ deposition to total precipitation (see Sect. 2.2.2). Figure 5 shows GEOS-Chem simulated annual mean BC deposition and GEOS-5 precipitation over Asia. The largest BC deposition over the Tibetan Plateau is in the Himalayas and the southeastern plateau (Fig. 5a), reflecting the proximity of strong BC sources in northern India and southwestern China (Lu et al., 2012) and the intense precipitation in the region (Fig. 5b). The northern plateau is heavily influenced by BC transported in the westerlies (Kopacz et al., 2011; Lu et al., 2012), but the lack of strong precipitation (Fig. 5b) results in considerably smaller BC deposition (Fig. 5a).

Table 2 shows $\mathrm{BC}$ concentrations in snow at 18 sites across the plateau. The concentrations are $30 \%$ lower during the monsoon season (June-September) than during the non-monsoon seasons (October-May), both in the observations and in the model. Here the monsoon and non-monsoon seasons are defined following $\mathrm{Xu}$ et al. (2009). The lowest $\mathrm{BC}$ concentrations in snow (minimum of $4.3 \mu \mathrm{g} \mathrm{kg}-1$ ) are in the northern slope of the Himalayas, while the highest values (maximum of $141 \mu \mathrm{g} \mathrm{kg}^{-1}$ ) are to the north of the plateau. Such spatial variation largely reflects the varying elevations of the sites. Ming et al. (2009a, 2013) have shown that observed $\mathrm{BC}$ concentration in snow over the Tibetan Plateau is inversely correlated with the elevation of a site, with lower concentrations at higher elevations. Our model 
results capture this spatial variation, but deviate from the observed concentrations by more than a factor of 2 at several sites in the Himalayas and the central plateau (Table 2).

Model results overestimate $\mathrm{BC}$ concentrations in snow during the monsoon season by a factor of 2-4 at three Himalayan sites: Zuoqiupu $\left(29.2^{\circ} \mathrm{N}, 96.9^{\circ} \mathrm{E} ; 5500 \mathrm{~m}\right.$ a.s.l. $)$, East Rongbuk $\left(28.0^{\circ} \mathrm{N}, 87.0^{\circ} \mathrm{E} ; 6500 \mathrm{~m}\right.$ a.s.1.), and Namunani $\left(30.4^{\circ} \mathrm{N}, 81.3^{\circ} \mathrm{E} ; 5900 \mathrm{~m}\right.$ a.s.l.) (Fig. 6). Model results using the lower bound of $\mathrm{BC}$ emissions still overestimate the concentrations at these three sites (Table 2). Wet scavenging accounts for more than $80 \%$ of the $\mathrm{BC}$ deposition over the Tibetan Plateau during the monsoon season in the model. The large overestimate implies either excessive wet deposition or inadequate precipitation or both in the Himalayas, given that $\mathrm{BC}$ concentration in snow is approximated here as the ratio of $\mathrm{BC}$ deposition to precipitation (see Sect. 2.2.2). Figure 7 shows the monthly precipitation over different parts of the Tibetan Plateau from the Global Precipitation Climatology Project (GPCP, Huffman et al., 2001), the NOAA Climate Prediction Center (CPC) Merged Analysis of Precipitation (CMAP, Xie and Arkin, 1997), the University of East Anglia Climate Research Unit (CRU, Harris et al., 2014) and GEOS5. GPCP precipitation is generally consistent with that from CMAP in most parts of the plateau except the southeastern plateau, where it is stronger by more than a factor of 2 . CRU precipitation tends to be much stronger than those from GPCP and CMAP during the monsoon season, particularly in the southeastern plateau and the Himalayas (Fig. 7). Previous studies have shown that the monsoon precipitation in the Himalayas is too weak in both GPCP and CMAP data (Kitoh and Kusunoki, 2008; Voisin et al., 2008) yet too strong in the CRU data (Zhao and Fu, 2006; Xie et al., 2007). The scarcity of observational sites and the complex terrain of the Himalayas are two of the principle reasons for large uncertainties in different precipitation data sets and apparent inconsistences among them (Ma et al., 2009; Andermann et al., 2011). Figure 7 shows that GEOS-5 precipitation is stronger than GPCP and CMAP data by a factor of 2 in the Himalayas during the monsoon season. To probe the sensitivity of $\mathrm{BC}$ deposition and our calculated $\mathrm{BC}$ concentration in snow in the Himalayas to precipitation, we conducted a GEOS-Chem simulation where we reduced GEOS-5 precipitation in the region by $20 \%$ during the monsoon season. The resulting $\mathrm{BC}$ wet deposition is only slightly lower (up to $5 \%$ ), rather insensitive to changes in presumably already intense precipitation during the monsoon season in the region. This lack of strong sensitivity reflects an already efficient wet scavenging of $\mathrm{BC}$ in the intense monsoon precipitation. The resulting $\mathrm{BC}$ concentrations in snow are higher by $18 \%$ on average in the region, because the reduced precipitation tends to concentrate $\mathrm{BC}$ in snow. Therefore, model overestimates of $\mathrm{BC}$ concentration in snow in the region are more likely resulting from excessive $\mathrm{BC}$ deposition than from excessive monsoon precipitation. This is likely a result of overlong BC lifetime due to insufficient wet removal. Wang et al. (2014) compared GEOS-Chem simulated atmospheric BC concentrations with the HIAPER Pole-to-Pole Observations (HIPPO) aircraft measurements and concluded that wet scavenging in the model is too weak. This is in part because of the underestimated scavenging efficiency of $\mathrm{BC}$ in the model. In addition, the relatively long $\mathrm{BC}$ aging time used in the model also potentially contributes to the weak wet scavenging. Recent observations suggest that the e-folding time of about 1 day, for the hydrophobic-to-hydrophilic conversion of $\mathrm{BC}$, typically used in global models is too long (Akagi et al., 2012). The uncertainties in wet scavenging in the model reduce the accuracy in the estimates of snow $\mathrm{BC}$ concentrations. Excessive $\mathrm{BC}$ deposition can in part result from excessively strong PBL mixing in the source regions and consequently excessive $\mathrm{BC}$ being transported into the free troposphere. Our model results show that the non-local boundary layer mixing (Lin and McElory, 2010) reduces BC wet deposition by up to $5 \%$ on average in the Himalayas during the monsoon season.

Figure 6 shows that our calculated BC concentrations in snow are lower than observations by a factor of 2 across the central plateau. Model results using the upper bound of $\mathrm{BC}$ emissions are able to reproduce the high $\mathrm{BC}$ concentrations in snow at La'nong but miss those high values at the other sites (Table 2). Ming et al. (2009a) pointed out that this region is predominantly influenced by biofuel burning (residential cooking and heating) and biomass burning from religious activities. These local emissions are largely unaccounted for in current emission inventories (Wang et al., 2012). In addition, it is likely that the lack of consideration of snow aging also lowers the $\mathrm{BC}$ concentration in snow computed here (Xu et al., 2006). We choose to exclude Meikuang and Zhadang from the comparison here on account of local emissions from coal-containing rock strata at the former $\mathrm{Xu}$ et al., 2006) and strong snow melting at the latter (Zhou et al., 2007). GEOS-5 precipitation in the central plateau is in general agreement with those from CMAP and CRU during the non-monsoon season and that from GPCP during the monsoon season (Fig. 7e).

Model results are consistent with observations at the elevated sites in the northwestern and northeastern plateau and to the north of the plateau (Fig. 6), where free tropospheric $\mathrm{BC}$ is primarily northern mid-latitude pollution transported by the westerlies (Kopacz et al., 2011; Lu et al., 2012). Regional emissions from western and central China also contribute to BC deposition in these regions (Lu et al., 2012). Although precipitation in these regions is weaker in GEOS5 than in GPCP and CMAP (Fig. 7b, d), previous studies have shown that GPCP and CMAP precipitation is likely too strong there (Voisin et al., 2008; Ma et al., 2009).

Overall model results of $\mathrm{BC}$ concentration in snow have a small negative bias but a large RMSE (Fig. 4, middle column); the latter results from the large discrepancies in the Himalayas and the central plateau. Model results are 


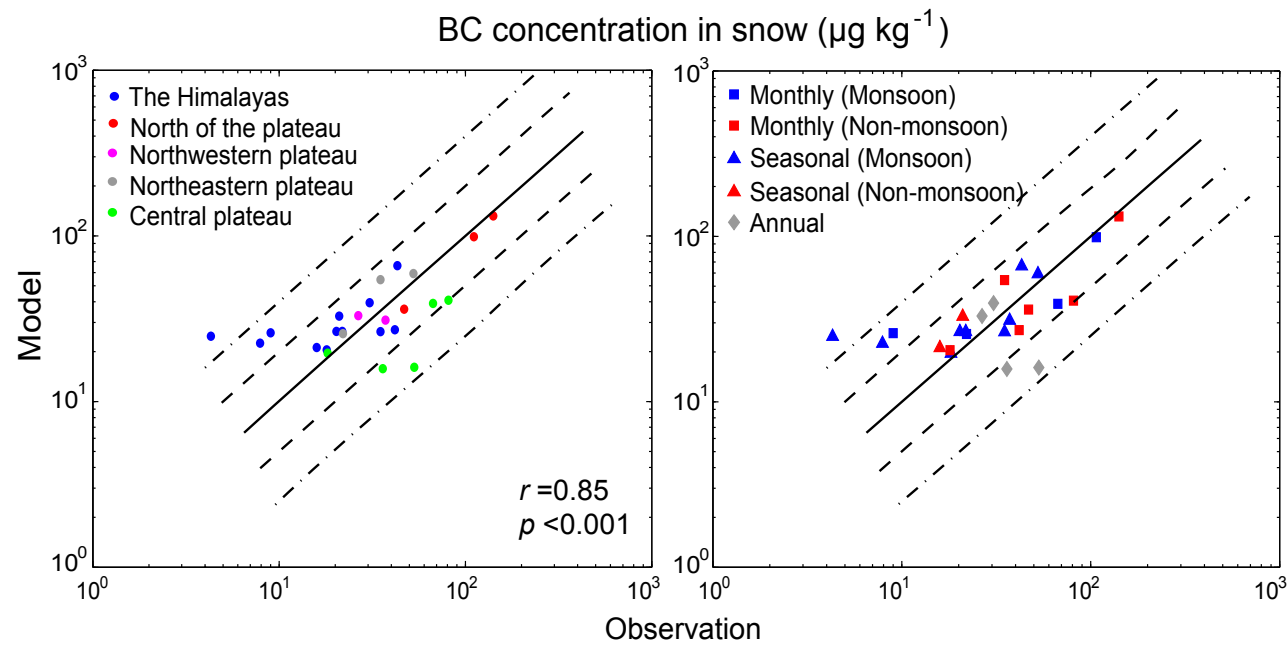

Figure 6. Observed and GEOS-Chem simulated monthly or seasonal mean BC concentration in snow ( $\left.\mu \mathrm{g} \mathrm{kg}^{-1}\right)$ at sites over the Tibetan Plateau (see Table 2 and Fig. 1). Left panel: sub-regions of the Tibetan Plateau are color-coded. Right panel: different temporal resolutions are symbol-coded: monthly - square; seasonal - triangle; annual - diamond, with blue for monsoon season and red for non-monsoon season. Solid lines are $1: 1$ ratio lines; dashed lines are $1: 2$ (or $2: 1$ ) ratio lines; dashed-dotted lines are $1: 4$ (or $4: 1$ ) ratio lines. Also shown are the correlation coefficient $(r)$ and $p$ value. Values are for 2006 unless stated otherwise. See text for details.

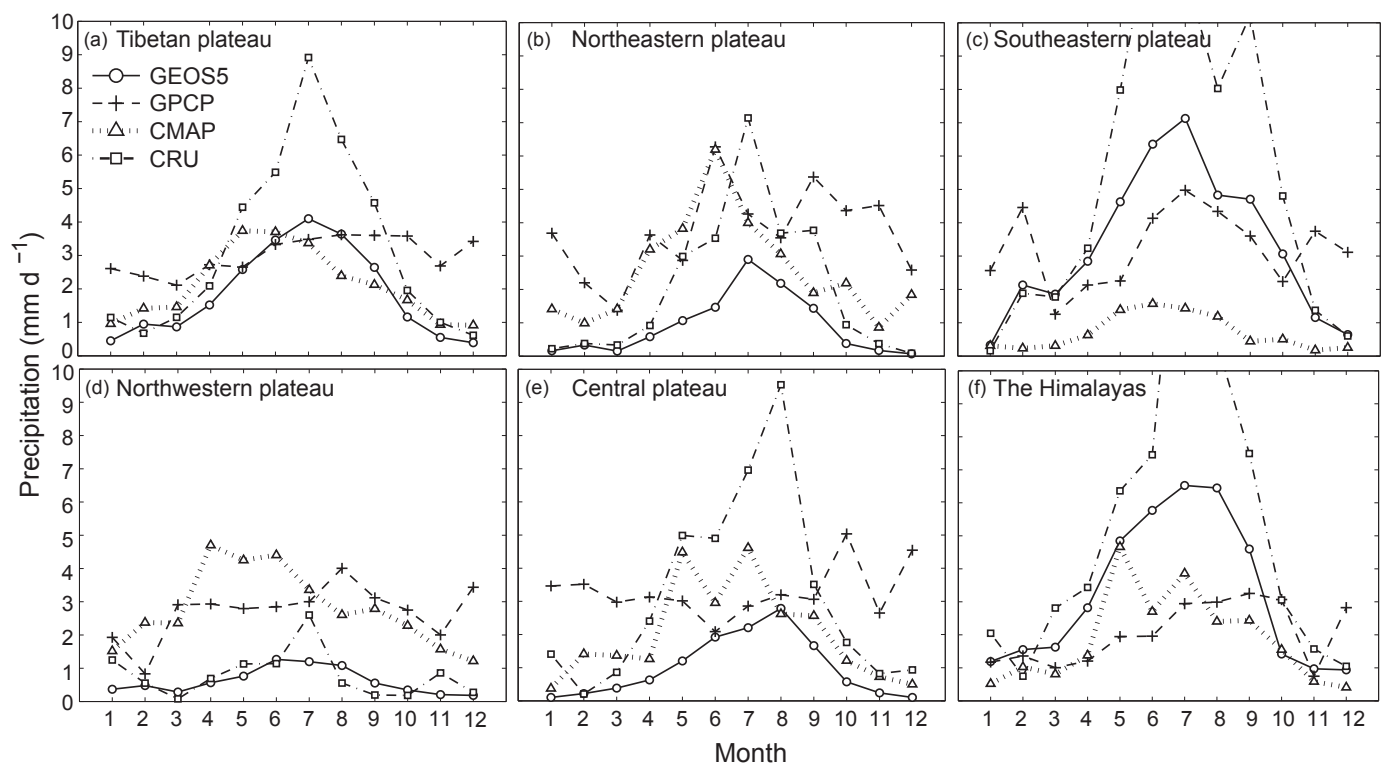

Figure 7. Monthly mean precipitation $\left(\mathrm{mm} \mathrm{d}^{-1}\right)$ in 2006, averaged over different parts of the Tibetan Plateau (see Fig. 1). Data are from the Goddard Earth Observing System Model version 5 data assimilation system (GEOS-5 DAS), Global Precipitation Climatology Project (GPCP), NOAA Climate Prediction Center (CPC) Merged Analysis of Precipitation (CMAP), and Climate Research Unit (CRU) of University of East Anglia.

statistically in good agreement with observations and reproduce the observed spatiotemporal variation $(r=0.85)$.

\subsection{BC AAOD}

Modeled BC AAOD is consistently lower than AERONET retrievals at most sites on both a monthly (Fig. 4, right column) and an annual bases (Table 3). The annual mean mod- eled BC AAOD over the Tibetan Plateau is 0.002 (Fig. 8), considerably lower than the observations. Model results somewhat capture the observed spatial and seasonal trends $(r=0.53)$, but to varying degrees underestimate the magnitudes (Fig. 9). Forty percent of the data points are too low by more than a factor of 2 in the model, particularly in the Himalayas and to the northwest of the plateau during winter 


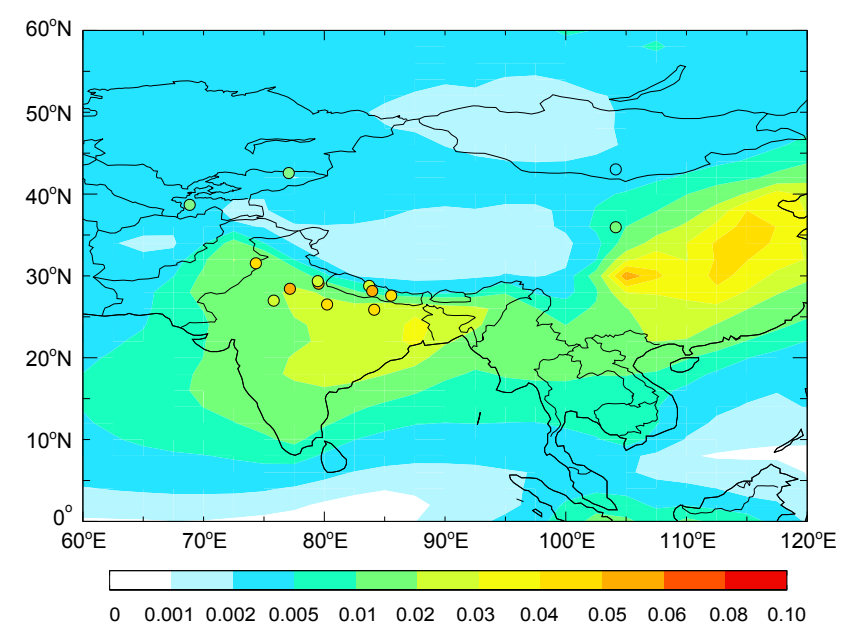

Figure 8. GEOS-Chem simulated annual mean BC AAOD (color contours) for 2006. Colored circles are values retrieved from AERONET observations (see Table 3).

and spring when emissions are larger (relative to emissions during the rest of the year). Most AERONET measurements in and around the plateau are after 2006, whereas our model results are for 2006. BC emissions in India have increased by $3.3 \% \mathrm{yr}^{-1}$ since 2006 (Lu et al., 2011). Therefore, the large low bias in part reflects the abovementioned temporal (hence emissions) mismatch. Using the upper bound of $\mathrm{BC}$ emissions reduces the model versus observations discrepancies at six sites (Table 3), but model results are still lower by a factor of 2 than the observed high AAODs at the other sites. We also note that there are large uncertainties in the AERONET AAOD retrieval (Bond et al., 2013), and that BC AAOD data are only scarcely available in the plateau and adjacent regions.

Another equally important factor contributing to the large discrepancy is the assumption of external mixing of $\mathrm{BC}$ in the model, which leads to a weaker BC absorption (Jacobson, 2001). Previous studies have found that BC absorption is enhanced by $50 \%$ because of internal mixing (Bond et al., 2006). We find that a $50 \%$ increase of BC absorption (using a MAC of $11 \mathrm{~m}^{2} \mathrm{~g}^{-1}$ in our calculation) would reduce the model bias by $57 \%$ in the Indo-Gangetic Plain and the northeastern plateau and to the northeast of the plateau, and by $16 \%$ along the southern slopes of the Himalayas and to the northwest of the plateau (Fig. 9, right panel). There is evidence that the enhancement of $\mathrm{BC}$ absorption due to internal mixing may be considerably smaller than previously thought (Cappa et al., 2012). It is clear that the large discrepancy (more than a factor of 2) in the Himalayas and to the northwest of the plateau cannot be fully explained by the lack of BC internal mixing consideration (and the associated larger absorption) in the model. Bond et al. (2013) pointed out that current models significantly underestimate BC AAOD, particularly in south and southeast Asia, primar- ily because of the absence of internal mixing and underestimated emissions. They recommended scaling up modeled BC AAOD to AERONET observations in order to accurately estimate $\mathrm{BC}$ radiative effects.

Therefore, although surface BC concentration is relatively well captured by model results (see Sect. 3.1), more measurements of vertical profiles over the Tibetan Plateau are imperative for evaluating column quantities such as BC AAOD.

\section{Sensitivity to $\mathrm{BC}$ emissions}

Figure 2 shows that model-simulated surface-BC concentrations are considerably lower in Experiment $B$ (using the INTEX-B inventory) relative to Experiment A (using the LU inventory) at rural sites. The difference in surface $\mathrm{BC}$ concentration is more than $30 \%$ at rural sites and $10-20 \%$ at remote sites, decreasing with distance from the source region. Such varying difference in surface BC concentration largely reflects the spatially non-uniform differences between the two emission inventories. The difference in $\mathrm{BC}$ concentration in snow between the two sets of results is less than $20 \%$. The relatively smaller difference is because the sites with measurements of BC concentration in snow are invariably remote high-elevation sites, further away from the source regions. $\mathrm{BC}$ concentrations in snow are higher over the northwestern and northeastern plateau and to the north of the plateau but lower in the Himalayas and the central plateau in Experiment $\mathrm{B}$ than in A. This is because the BC emissions in the central plateau and India are lower, and the emissions in northwestern and central China are higher in the INTEX-B than in the LU inventories. BC AAOD values are higher $(<15 \%)$ to the northeast and northwest of the plateau and lower (10$60 \%$ ) in the Indo-Gangetic Plain in Experiment B than in A. Therefore, both surface BC concentration and AAOD along the southern slope of the Himalayas are strongly sensitive to Indian emissions, while the high-altitude remote sites are less affected by the emission changes in the source regions. Overall, Experiment B results show larger negative bias and root-mean-square error (RMSE) (Table 6) and lower Taylor score (Fig. 10) relative to Experiment A. As such, our results suggest that the INTEX-B inventory considerably underestimates anthropogenic BC emissions in India, which is also implied by some latest estimates of BC emissions in Asia (Kurokawa et al., 2013; Wang et al., 2014).

\section{Sensitivity to $\mathrm{BC}$ aging parameterization}

Compared with model results from the standard simulation (Experiment A, Table 5), the use of Liu et al. (2011) parameterization for $\mathrm{BC}$ aging in the model (Experiment $\mathrm{C}$, Table 5) results in increased surface- $\mathrm{BC}$ concentrations, $\mathrm{BC}$ concentrations in snow, and BC AAOD, because of the longer BC atmospheric lifetime against wet scavenging (see Sect. 2.2.3). The increase in surface $\mathrm{BC}$ concentration is $1 \%$ on average 


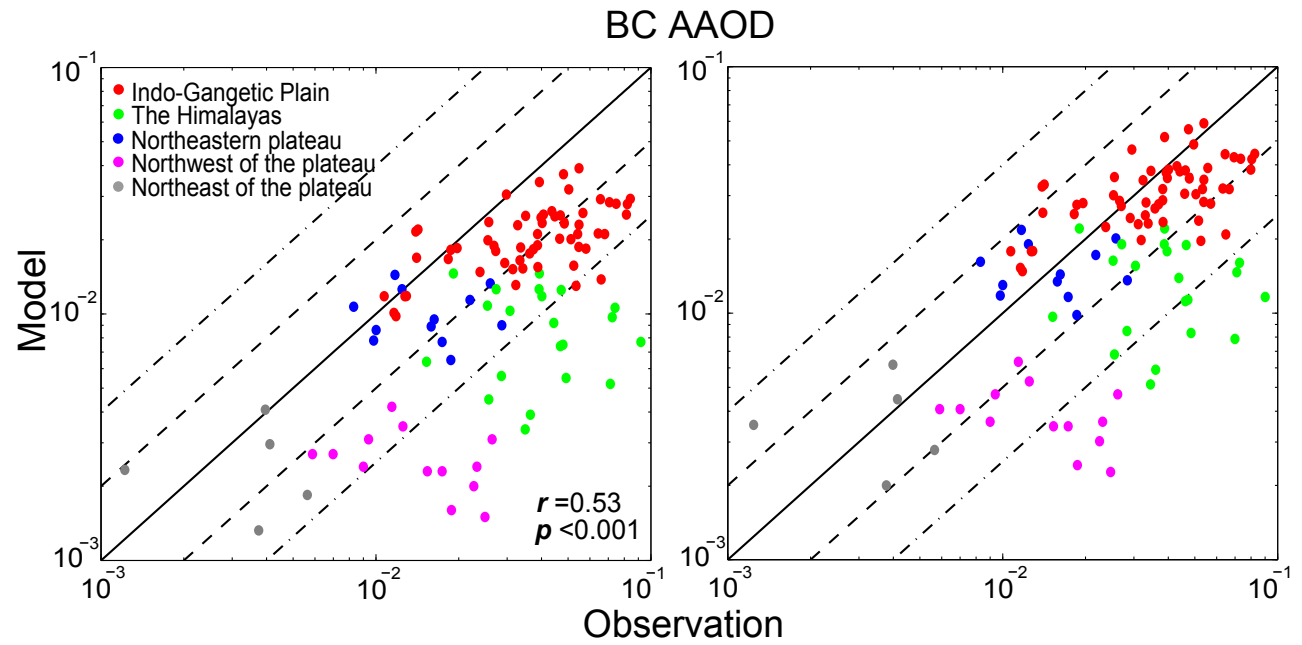

Figure 9. Observed and GEOS-Chem simulated monthly mean BC AAOD at AERONET sites over the Tibetan Plateau (see Table 3 and Fig. 1). Left panel: assuming external mixing of BC. Right panel: assuming a $50 \%$ increase of BC absorption associated with internal mixing. Regions are color-coded: Indo-Gangetic Plain (red), the Himalayas (green), the northeastern plateau (blue), northeast of the plateau (grey), northwest of the plateau (magenta). Solid line is a $1: 1$ ratio line; dashed lines are $1: 2$ (or $2: 1$ ) ratio lines; dashed-dotted lines are $1: 4$ (or $4: 1)$ ratio lines. Also shown are the correlation coefficient $(r)$ and $p$ value. Values are for 2006 unless stated otherwise. See text for details.

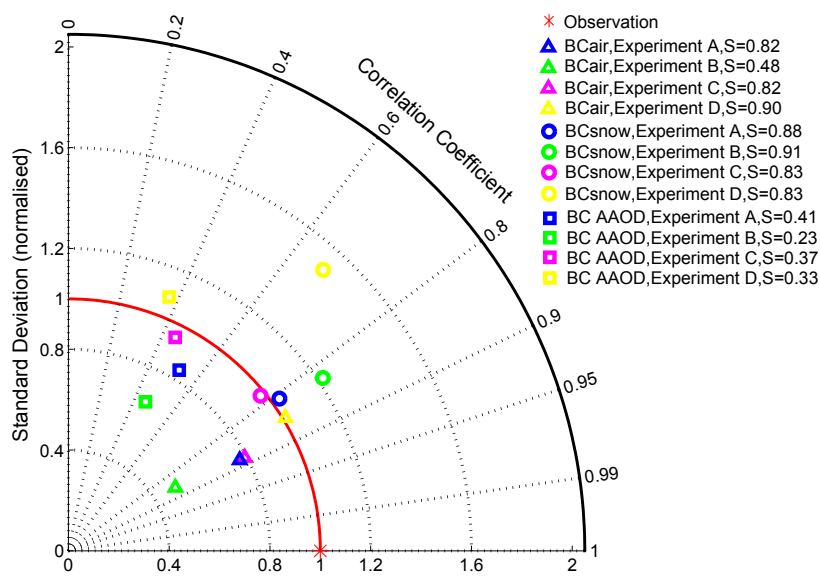

Figure 10. Taylor diagram of GEOS-Chem simulated versus observed $\mathrm{BC}$ concentration in surface air $\left(\mathrm{BC}_{\mathrm{air}}\right)$ and in snow $\left(\mathrm{BC}_{\text {snow }}\right)$, and $\mathrm{BC} \mathrm{AAOD}$ at sites over the Tibetan Plateau (see Tables 1, 2 and 3 and Fig. 1). Red asterisk is the observation. Triangles, circles and squares, respectively, indicate modeled $\mathrm{BC}_{\mathrm{air}}, \mathrm{BC}_{\mathrm{snow}}$, and BC AAOD from Experiments A (blue), B (green), C (magenta) and D (yellow). See Table 5 and text for more details on the model experiments. Also shown are the Taylor scores (S). Values are for 2006 unless stated otherwise. See text for details.

(maximum $3 \%$ ) at rural sites and $10 \%$ on average (maximum $30 \%$ ) at remote sites (Fig. 2). This is consistent with the results from Huang et al. (2013), where the use of Liu et al. (2011) parameterization only changes GEOS-Chem simulated surface-BC concentrations by less than $0.01 \mu \mathrm{g} \mathrm{m}^{-3}$ in the Tibetan Plateau. Liu et al. (2011) showed that their aging parameterization significantly improves seasonal variations of modeled surface-BC concentrations in the Arctic. This is different from the present study, where the aging parameterization has a minor impact on the seasonality of both surface BC concentrations and AAOD (Fig. 2 and Table 6). The increase in BC AAOD is $10 \%$ on average (maximum $30 \%$ ) at most AERONET sites but leads to lower spatiotemporal correlations with observations (Table 6). The aging parameterization has a much stronger impact on modeled BC concentration in snow than on surface $\mathrm{BC}$ concentration and $\mathrm{BC}$ AAOD. The increase in $\mathrm{BC}$ concentration in snow is more than $30 \%$ at a number of sites in the Himalayas and the central plateau (Table 2). Compared with the standard simulation (Experiment A), the use of the Liu et al. (2011) parameterization results in an overestimate of $\mathrm{BC}$ concentration in snow relative to observations, which increases the absolute bias by a factor of 2 (Table 6 ) and decreases the Taylor score (Fig. 10). This suggests that the Liu et al. (2011) aging parameterization may result in excessively long $\mathrm{BC}$-conversion times (from hydrophobic to hydrophilic) and hence excessively long atmospheric lifetimes.

\section{Sensitivity to model resolution}

Compared with model results from the standard simulation (Experiment A, Table 5), the use of a finer model resolution $\left(0.5^{\circ} \times 0.667^{\circ}\right)$ nested over Asia (Experiment D, Table 5) reduces the bias in modeled surface-BC concentrations from 15 to $2 \%$ but increases the RMSE (Table 6). Wang et al. (2014) found that replacing a coarse-resolution model $\left(1.27^{\circ} \times 2.5^{\circ}\right)$ with a finer-resolution one $\left(0.51^{\circ} \times 0.66^{\circ}\right)$ reduces the bias of surface BC simulation in Asia by $30 \%$. Figure 2 shows 
Table 6. Error statistics of GEOS-Chem simulations of BC in the Tibetan Plateau for 2006.

\begin{tabular}{|c|c|c|c|c|c|c|c|c|c|c|c|c|}
\hline \multirow{3}{*}{$\begin{array}{l}\text { Statistical } \\
\text { quantities* }\end{array}$} & \multicolumn{4}{|c|}{$\mathrm{BC}$ in surface air } & \multicolumn{4}{|c|}{$\mathrm{BC}$ in snow } & \multicolumn{4}{|c|}{ BC AAOD } \\
\hline & \multicolumn{12}{|c|}{ Model experiments (see Table 5) } \\
\hline & A & B & $\mathrm{C}$ & $\mathrm{D}$ & A & B & $\mathrm{C}$ & $\mathrm{D}$ & A & B & $\mathrm{C}$ & $\mathrm{D}$ \\
\hline Mean error & -0.29 & -0.82 & -0.26 & -0.03 & -1.23 & -0.75 & 3.39 & 1.94 & -0.019 & -0.023 & -0.020 & -0.020 \\
\hline Mean absolute error & 0.59 & 0.93 & 0.59 & 0.74 & 13.39 & 12.74 & 16.09 & 19.67 & 0.020 & 0.023 & 0.020 & 0.021 \\
\hline Fractional gross error & 0.39 & 0.46 & 0.39 & 0.46 & 0.43 & 0.40 & 0.48 & 0.58 & 0.78 & 0.93 & 0.80 & 0.77 \\
\hline Root-mean-square error (RMSE) & 1.34 & 1.95 & 1.33 & 1.33 & 16.73 & 16.65 & 18.67 & 24.54 & 0.026 & 0.029 & 0.027 & 0.027 \\
\hline Bias-corrected RMSE & 1.31 & 1.77 & 1.30 & 1.33 & 16.69 & 16.63 & 18.36 & 24.46 & 0.017 & 0.018 & 0.018 & 0.019 \\
\hline Correlation coefficient $(p$ value $<0.001$ ) & 0.90 & 0.87 & 0.90 & 0.87 & 0.85 & 0.86 & 0.81 & 0.70 & 0.53 & 0.46 & 0.45 & 0.37 \\
\hline
\end{tabular}

${ }^{*}$ Units for mean error, mean absolute error, RMSE and bias-corrected RMSE are $\mu \mathrm{g} \mathrm{m}^{-3}$ for BC in surface air and $\mu \mathrm{g} \mathrm{kg}{ }^{-1}$ for BC in snow.

that the nested model simulation slightly improves seasonal variations of surface $\mathrm{BC}$ concentrations at several remote sites, whereas it does not improve those at urban sites both in magnitude and in temporal variation (Fig. 3). This is similar to the results in Fu et al. (2012), where the GEOS-Chem nested model underestimates surface $\mathrm{BC}$ concentrations by an order of magnitude at Dunhuang and Lhasa sites, even using the enhanced $\mathrm{BC}$ emissions from top-down estimates. Compared with the standard simulation, the nested model simulation increases the absolute bias by $57 \%$ in modeled snow-BC concentration and by $5 \%$ in modeled BC AAOD (Table 6). The nested model results also show a lower spatiotemporal correlation with observations of snow BC concentration and BC AAOD (Fig. 10). Our results suggest that the finer model resolution alone cannot explain model versus observation discrepancies on the simulation of snow BC concentration and BC AAOD in the Tibetan Plateau.

\section{Summary and conclusions}

This study sought to understand the capability of GEOSChem in simulating BC over the Tibetan Plateau and the potential factors driving model versus observation discrepancies. We used GEOS-Chem version 9-01-03 driven by GEOS-5 assimilated meteorological fields and systematically evaluated the model simulations against in situ measurements of BC in surface air, BC in snow, and BC AAOD for 2006. We also examined the effects of anthropogenic $\mathrm{BC}$ emissions from China and India, $\mathrm{BC}$ aging process and model resolution on $\mathrm{BC}$ simulations.

Model results captured the seasonal variation of surface $\mathrm{BC}$ concentrations at rural sites, but the observed wintertime high values were absent in the model, which calls for improved emission estimates particularly in the Indo-Gangetic Plain. The use of non-local PBL mixing scheme reduced part of the discrepancy between observed and modeled surface$\mathrm{BC}$ concentrations in winter. Modeled surface-BC concentrations at remote sites were within a factor of 2 of the observations. Part of the discrepancy is explained by the inherent difficulty in simulating the meteorological fields over the complex Himalayan terrain. Surface BC concentrations at urban sites are significantly underestimated by model results.

Modeled BC concentrations in snow were spatiotemporally consistent with observations $(r=0.85)$. The highest snow BC concentrations were seen north of the plateau (40$50^{\circ} \mathrm{N}$ ), while the lowest values were found in the northern slope of the Himalayas. However, model results were a factor of 2-4 higher than the observations at three Himalayan sites during the monsoon, primarily because of the excessive $\mathrm{BC}$ deposition resulted from overlong $\mathrm{BC}$ lifetime. Model results underestimated snow $\mathrm{BC}$ concentration by a factor of 2 in the central plateau, due to the lack of snow aging in the CTM and the strong local emissions unaccounted for in the emission inventories. Model results are consistent with the observations at the elevated sites in the northwestern and northeastern plateau and to the north of the plateau. Model results of both BC in snow and in surface air showed no statistically significant difference with observations with biases less than $15 \%$.

Modeled BC AAOD is consistently biased low at most AERONET sites over the plateau, especially to the northwest of the plateau and in the Himalayas in winter and spring. The large model versus observation discrepancies were mainly because of underestimated emissions and the assumption of external mixing of $\mathrm{BC}$ in the model. This suggests that modeled BC AAOD should be scaled to AERONET observations in order to accurately estimate BC climatic effects. More measurements of vertical profiles over the Tibetan Plateau are imperative for evaluating modeled column quantities such as BC AAOD.

Sensitivity simulations showed that both surface BC concentration and BC AAOD along the southern slope of the Himalayas were strongly sensitive to Indian emissions, while the elevated remote sites were less affected by the change of emissions in source regions. The $\mathrm{BC}$ aging parameterization from Liu et al. (2011) resulted in a large increase of $\mathrm{BC}$ concentration in snow, but only had a minor impact on surface $\mathrm{BC}$ concentration and AAOD. The use of a finer model resolution nested over Asia reduced the bias in modeled surface-BC concentration from 15 to $2 \%$, but increased 
the bias in modeled snow-BC concentration and BC AAOD by $57 \%$ and $5 \%$, respectively. More quantitative analyses are required to investigate the uncertainties in different model processes of BC simulations.

Therefore, accurate model simulations of $\mathrm{BC}$ in surface air, BC in snow and BC AAOD over the Tibetan Plateau require improvements in $\mathrm{BC}$ emission inventories particularly for China and India, model meteorological fields over the complex Himalayan terrain, PBL mixing scheme particularly under a stable PBL condition, model representation of atmospheric BC aging process including the conversion of hydrophobic to hydrophilic $\mathrm{BC}$ and the enhancement of $\mathrm{BC}$ absorption resulted from internal mixing, model parameterization of BC wet scavenging, and model simulation of snow processes such as snow aging, snow melting and $\mathrm{BC}$ transfer among different snow layers.

Acknowledgements. We thank three reviewers for their constructive comments. We thank Paolo Bonasoni, Angela Marinoni, Stefano Decesari, Krishnaswamy Krishnamoorthy, Suresh Babu, and Monika Kopacz for offering useful information. We thank James T. Randerson for providing biomass burning emissions with small fires. K. Ram thanks Department of Science and Technology, Govt. of India for providing financial support under the INSPIRE Faculty scheme (no. DST/INSPIRE Faculty Award/2012; IFA-AES-02). This study also used the data collected within the SHARE Project thanks to contributions from the Italian National Research Council and the Italian Ministry of Foreign Affairs. This study was funded by NASA grants NNX09AF07G and NNX08AF64G from the Atmospheric Chemistry Modeling and Analysis Program (ACMAP).

Edited by: Y. Balkanski

\section{References}

Akagi, S. K., Craven, J. S., Taylor, J. W., McMeeking, G. R., Yokelson, R. J., Burling, I. R., Urbanski, S. P., Wold, C. E., Seinfeld, J. H., Coe, H., Alvarado, M. J., and Weise, D. R.: Evolution of trace gases and particles emitted by a chaparral fire in California, Atmos. Chem. Phys., 12, 1397-1421, doi:10.5194/acp-12-13972012, 2012.

Allen, D. J., Rood, R. B., Thompson, A. M., and Hudson, R. D.: Three-dimensional radon 222 calculations using assimilated meteorological data and a convective mixing algorithm, J. Geophys. Res.-Atmos., 101, 6871-6881, doi:10.1029/95jd03408, 1996a.

Allen, D. J., Kasibhatla, P., Thompson, A. M., Rood, R. B., Doddridge, B. G., Pickering, K. E., Hudson, R. D., and Lin, S. J.: Transport-induced interannual variability of carbon monoxide determined using a chemistry and transport model, J. Geophys. Res.-Atmos., 101, 28655-28669, doi:10.1029/96jd02984, 1996b.

Andermann, C., Bonnet, S., and Gloaguen, R.: Evaluation of precipitation data sets along the Himalayan front, Geochem. Geophy. Geosy., 12, Q07023, doi:10.1029/2011gc003513, 2011.

Arakawa, A., and Schubert, W. H.: Interaction of a $\mathrm{Cu}-$ mulus Cloud Ensemble with Large-Scale Environment
1., J. Atmos. Sci., 31, 674-701, doi:10.1175/15200469(1974)031<0674:IOACCE> 2.0.CO;2, 1974.

Barnett, T. P., Adam, J. C., and Lettenmaier, D. P.: Potential impacts of a warming climate on water availability in snow-dominated regions, Nature, 438, 303-309, doi:10.1038/Nature04141, 2005.

Beegum, S. N., Moorthy, K. K., Babu, S. S., Satheesh, S. K., Vinoj, V., Badarinath, K. V. S., Safai, P. D., Devara, P. C. S., Singh, S., Vinod, Durnka, U. C., and Pant, P.: Spatial distribution of aerosol black carbon over India during pre-monsoon season, Atmos. Environ., 43, 1071-1078, doi:10.1016/j.atmosenv.2008.11.042, 2009.

Bey, I., Jacob, D. J., Yantosca, R. M., Logan, J. A., Field, B. D., Fiore, A. M., Li, Q. B., Liu, H. G. Y., Mickley, L. J., and Schultz, M. G.: Global modeling of tropospheric chemistry with assimilated meteorology: Model description and evaluation, J. Geophys. Res., 106, 23073-23095, doi:10.1029/2001jd000807, 2001.

Bonasoni, P., Laj, P., Marinoni, A., Sprenger, M., Angelini, F., Arduini, J., Bonafe, U., Calzolari, F., Colombo, T., Decesari, S., Di Biagio, C., di Sarra, A. G., Evangelisti, F., Duchi, R., Facchini, M. C., Fuzzi, S., Gobbi, G. P., Maione, M., Panday, A., Roccato, F., Sellegri, K., Venzac, H., Verza, G. P., Villani, P., Vuillermoz, E., and Cristofanelli, P.: Atmospheric Brown Clouds in the Himalayas: first two years of continuous observations at the Nepal Climate Observatory-Pyramid (5079 m), Atmos. Chem. Phys., 10, 7515-7531, doi:10.5194/acp-10-7515-2010, 2010.

Bond, T. C., Anderson, T. L., and Campbell, D.: Calibration and intercomparison of filter-based measurements of visible light absorption by aerosols, Aerosol Sci. Tech., 30, 582-600, doi:10.1080/027868299304435, 1999.

Bond, T. C., Streets, D. G., Yarber, K. F., Nelson, S. M., Woo, J. H., and Klimont, Z.: A technology-based global inventory of black and organic carbon emissions from combustion, J. Geophys. Res., 109, D14203, doi:10.1029/2003jd003697, 2004.

Bond, T. C., and Bergstrom, R. W.: Light absorption by carbonaceous particles: An investigative review, Aerosol Sci. Tech., 40, 27-67, doi:10.1080/02786820500421521, 2006.

Bond, T. C., Habib, G., and Bergstrom, R. W.: Limitations in the enhancement of visible light absorption due to mixing state, J. Geophys. Res.-Atmos, 111, D20211, doi:10.1029/2006jd007315, 2006.

Bond, T. C., Bhardwaj, E., Dong, R., Jogani, R., Jung, S. K., Roden, C., Streets, D. G., and Trautmann, N. M.: Historical emissions of black and organic carbon aerosol from energy-related combustion, 1850-2000, Global Biogeochem. Cy., 21, Gb2018, doi:10.1029/2006gb002840, 2007.

Bond, T. C., Doherty, S. J., Fahey, D. W., Forster, P. M., Berntsen, T., DeAngelo, B. J., Flanner, M. G., Ghan, S., Kärcher, B., Koch, D., Kinne, S., Kondo, Y., Quinn, P. K., Sarofim, M. C., Schultz, M. G., Schulz, M., Venkataraman, C., Zhang, H., Zhang, S., Bellouin, N., Guttikunda, S. K., Hopke, P. K., Jacobson, M. Z., Kaiser, J. W., Klimont, Z., Lohmann, U., Schwarz, J P., Shindell, D., Storelvmo, T., Warren, S. G., and Zender, C. S.: Bounding the role of black carbon in the climate system: A scientific assessment, J. Geophys. Res.-Atmos., 118, 1-173, doi:10.1002/jgrd.50171, 2013.

Cachier, H. and Pertuisot, M. H.: Particulate carbon in Arctic ice, Analysis Magazine, 22, 34-37, 1994. 
Carrico, C. M., Bergin, M. H., Shrestha, A. B., Dibb, J. E., Gomes, L., and Harris, J. M.: The importance of carbon and mineral dust to seasonal aerosol properties in the Nepal Himalaya, Atmos. Environ., 37, 2811-2824, doi:10.1016/S1352-2310(03)00197-3, 2003.

Cappa, C. D., Onasch, T. B., Massoli, P., Worsnop, D. R., Bates, T. S., Cross, E. S., Davidovits, P., Hakala, J., Hayden, K. L., Jobson, B. T., Kolesar, K. R., Lack, D. A., Lerner, B. M., Li, S. M., Mellon, D., Nuaaman, I., Olfert, J. S., Petaja, T., Quinn, P. K., Song, C., Subramanian, R., Williams, E. J., and Zaveri, R. A.: Radiative Absorption Enhancements Due to the Mixing State of Atmospheric Black Carbon, Science, 337, 1078-1081, doi:10.1126/science.1223447, 2012.

Chen, D., Wang, Y., McElroy, M. B., He, K., Yantosca, R. M., and Le Sager, P.: Regional CO pollution and export in China simulated by the high-resolution nested-grid GEOS-Chem model, Atmos. Chem. Phys., 9, 3825-3839, doi:10.5194/acp-9-3825-2009, 2009.

Chow, J. C., Watson, J. G., Chen, L. W. A., Arnott, W. P., Moosmuller, H., and Fung, K.: Equivalence of elemental carbon by thermal/optical reflectance and transmittance with different temperature protocols, Environ. Sci. Technol., 38, 4414-4422, doi:10.1021/Es034936u, 2004.

Clarke, A. D., Shinozuka, Y., Kapustin, V. N., Howell, S., Huebert, B., Doherty, S., Anderson, T., Covert, D., Anderson, J., Hua, X., Moore, K. G., McNaughton, C., Carmichael, G., and Weber, R.: Size distributions and mixtures of dust and black carbon aerosol in Asian outflow: Physiochemistry and optical properties, J. Geophys. Res.-Atmos., 109, D15S09, doi:10.1029/2003jd004378, 2004.

Cooke, W. F., Liousse, C., Cachier, H., and Feichter, J.: Construction of a 1 degrees $x 1$ degrees fossil fuel emission data set for carbonaceous aerosol and implementation and radiative impact in the ECHAM4 model, J. Geophys. Res.-Atmos., 104, $22137-$ 22162, doi:10.1029/1999jd900187, 1999.

Donner, L. J., Wyman, B. L., Hemler, R. S., Horowitz, L. W., Ming, Y., Zhao, M., Golaz, J. C., Ginoux, P., Lin, S. J., Schwarzkopf, M. D., Austin, J., Alaka, G., Cooke, W. F., Delworth, T. L., Freidenreich, S. M., Gordon, C. T., Griffies, S. M., Held, I. M., Hurlin, W. J., Klein, S. A., Knutson, T. R., Langenhorst, A. R., Lee, H. C., Lin, Y. L., Magi, B. I., Malyshev, S. L., Milly, P. C. D., Naik, V., Nath, M. J., Pincus, R., Ploshay, J. J., Ramaswamy, V., Seman, C. J., Shevliakova, E., Sirutis, J. J., Stern, W. F., Stouffer, R. J., Wilson, R. J., Winton, M., Wittenberg, A. T., and Zeng, F. R.: The Dynamical Core, Physical Parameterizations, and Basic Simulation Characteristics of the Atmospheric Component AM3 of the GFDL Global Coupled Model CM3, J. Climate, 24, 3484 3519, doi:10.1175/2011jcli3955.1, 2011.

Dubovik, O., and King, M. D.: A flexible inversion algorithm for retrieval of aerosol optical properties from Sun and sky radiance measurements, J. Geophys. Res.-Atmos., 105, 20673-20696, doi:10.1029/2000jd900282, 2000.

Emery, C., Jung, J., Downey, N., Johnson, J., Jimenez, M., Yarvvood, G., and Morris, R.: Regional and global modeling estimates of policy relevant background ozone over the United States, Atmos. Environ., 47, 206-217, doi:10.1016/j.atmosenv.2011.11.012, 2012.
Fairlie, T. D., Jacob, D. J., and Park, R. J.: The impact of transpacific transport of mineral dust in the United States, Atmos. Environ., 41, 1251-1266, doi:10.1016/j.atmosenv.2006.09.048, 2007.

Flanner, M. G., Zender, C. S., Randerson, J. T., and Rasch, P. J.: Present-day climate forcing and response from black carbon in snow, J. Geophys. Res.-Atmos., 112, D11202, doi:10.1029/2006jd008003, 2007.

Flanner, M. G., Zender, C. S., Hess, P. G., Mahowald, N. M., Painter, T. H., Ramanathan, V., and Rasch, P. J.: Springtime warming and reduced snow cover from carbonaceous particles, Atmos. Chem. Phys., 9, 2481-2497, doi:10.5194/acp-9-24812009, 2009.

Friedman, B., Herich, H., Kammermann, L., Gross, D. S., Arneth, A., Holst, T., and Cziczo, D. J.: Subarctic atmospheric aerosol composition: 1. Ambient aerosol characterization, J. Geophys. Res.-Atmos., 114, D13203, doi:10.1029/2009jd011772, 2009.

Fu, T. M., Cao, J. J., Zhang, X. Y., Lee, S. C., Zhang, Q., Han, Y. M., Qu, W. J., Han, Z., Zhang, R., Wang, Y. X., Chen, D., and Henze, D. K.: Carbonaceous aerosols in China: top-down constraints on primary sources and estimation of secondary contribution, Atmos. Chem. Phys., 12, 2725-2746, doi:10.5194/acp12-2725-2012, 2012.

Ganguly, D., Ginoux, P., Ramaswamy, V., Dubovik, O., Welton, J., Reid, E. A., and Holben, B. N.: Inferring the composition and concentration of aerosols by combining AERONET and MPLNET data: Comparison with other measurements and utilization to evaluate GCM output, J. Geophys. Res.-Atmos., 114, D16203, doi:10.1029/2009jd011895, 2009a.

Ganguly, D., Ginoux, P., Ramaswamy, V., Winker, D. M., Holben, B. N., and Tripathi, S. N.: Retrieving the composition and concentration of aerosols over the Indo-Gangetic basin using CALIOP and AERONET data, Geophys. Res. Lett., 36, L13806, doi:10.1029/2009gl038315, 2009b.

Granier, C., Bessagnet, B., Bond, T., D’Angiola, A., van der Gon, H. D., Frost, G. J., Heil, A., Kaiser, J. W., Kinne, S., Klimont, Z., Kloster, S., Lamarque, J. F., Liousse, C., Masui, T., Meleux, F., Mieville, A., Ohara, T., Raut, J. C., Riahi, K., Schultz, M. G., Smith, S. J., Thompson, A., van Aardenne, J., van der Werf, G. R., and van Vuuren, D. P.: Evolution of anthropogenic and biomass burning emissions of air pollutants at global and regional scales during the 1980-2010 period, Climatic Change, 109, 163-190, doi:10.1007/s10584-011-0154-1, 2011.

Hack, J. J.: Parameterization of moist convection in the National Center for Atmospheric Research community climate model (CCM2), J. Geophys. Res.-Atmos., 99, 5551-5568, doi:10.1029/93jd03478, 1994.

Hansen, J., and Nazarenko, L.: Soot climate forcing via snow and ice albedos, P. Natl. Acad. Sci. USA, 101, 423-428, doi:10.1073/pnas.2237157100, 2004.

Harris, I., Jones, P. D., Osborn, T. J., and Lister, D. H.: Updated high-resolution grids of monthly climatic observations - the CRU TS3.10 Dataset, Int. J. Climatol., 34, 623-642, doi:10.1002/joc.3711, 2014.

Holtslag, A. A. M., and Boville, B. A.: Local Versus Nonlocal Boundary-Layer Diffusion in a Global Climate Model, J. Climate, 6, 1825-1842, doi:10.1175/15200442(1993)006<1825:Lvnbld> 2.0.Co;2, 1993.

Huang, Y., Wu, S., Dubey, M. K., and French, N. H. F.: Impact of aging mechanism on model simulated carbonaceous aerosols, 
Atmos. Chem. Phys., 13, 6329-6343, doi:10.5194/acp-13-63292013, 2013

Huffman, G. J., Adler, R. F., Morrissey, M. M., Bolvin, D. T., Curtis, S., Joyce, R., McGavock, B., and Susskind, J.: Global precipitation at one-degree daily resolution from multisatellite observations, J. Hydrometeorol., 2, 36-50, doi:10.1175/15257541(2001)002<0036:Gpaodd> 2.0.Co;2, 2001.

Immerzeel, W. W., van Beek, L. P. H., and Bierkens, M. F. P.: Climate Change Will Affect the Asian Water Towers, Science, 328, 1382-1385, doi:10.1126/science.1183188, 2010.

Jacobson, M. Z.: Strong radiative heating due to the mixing state of black carbon in atmospheric aerosols, Nature, 409, 695-697, doi:10.1038/35055518, 2001.

Jacobson, M. Z.: Climate response of fossil fuel and biofuel soot, accounting for soot's feedback to snow and sea ice albedo and emissivity, J. Geophys. Res.-Atmos., 109, D21201, doi:10.1029/2004jd004945, 2004.

Jacobson, M. Z.: Effects of externally-through-internally-mixed soot inclusions within clouds and precipitation on global climate, J. Phys. Chem. A., 110, 6860-6873, doi:10.1021/Jp056391r, 2006.

Kaiser, J. W., Heil, A., Andreae, M. O., Benedetti, A., Chubarova, N., Jones, L., Morcrette, J. J., Razinger, M., Schultz, M. G., Suttie, M., and van der Werf, G. R.: Biomass burning emissions estimated with a global fire assimilation system based on observed fire radiative power, Biogeosciences, 9, 527-554, doi:10.5194/bg-9-527-2012, 2012.

Khalizov, A. F., Zhang, R. Y., Zhang, D., Xue, H. X., Pagels, J., and McMurry, P. H.: Formation of highly hygroscopic soot aerosols upon internal mixing with sulfuric acid vapor, J. Geophys. Res.Atmos., 114, D05208, doi:10.1029/2008jd010595, 2009.

Kitoh, A. and Kusunoki, S.: East Asian summer monsoon simulation by a 20-km mesh AGCM, Clim. Dynam., 31, 389-401, doi:10.1007/s00382-007-0285-2, 2008.

Koch, D., Schulz, M., Kinne, S., McNaughton, C., Spackman, J. R., Balkanski, Y., Bauer, S., Berntsen, T., Bond, T. C., Boucher, O., Chin, M., Clarke, A., De Luca, N., Dentener, F., Diehl, T., Dubovik, O., Easter, R., Fahey, D. W., Feichter, J., Fillmore, D., Freitag, S., Ghan, S., Ginoux, P., Gong, S., Horowitz, L., Iversen, T., Kirkevåg, A., Klimont, Z., Kondo, Y., Krol, M., Liu, X., Miller, R., Montanaro, V., Moteki, N., Myhre, G., Penner, J. E., Perlwitz, J., Pitari, G., Reddy, S., Sahu, L., Sakamoto, H., Schuster, G., Schwarz, J. P., Seland, Ø., Stier, P., Takegawa, N., Takemura, T., Textor, C., van Aardenne, J. A., and Zhao, Y.: Evaluation of black carbon estimations in global aerosol models, Atmos. Chem. Phys., 9, 9001-9026, doi:10.5194/acp-9-9001-2009, 2009.

Kopacz, M., Mauzerall, D. L., Wang, J., Leibensperger, E. M., Henze, D. K., and Singh, K.: Origin and radiative forcing of black carbon transported to the Himalayas and Tibetan Plateau, Atmos. Chem. Phys., 11, 2837-2852, doi:10.5194/acp-11-28372011, 2011.

Kurokawa, J., Ohara, T., Morikawa, T., Hanayama, S., JanssensMaenhout, G., Fukui, T., Kawashima, K., and Akimoto, H.: Emissions of air pollutants and greenhouse gases over Asian regions during 2000-2008: Regional Emission inventory in ASia (REAS) version 2, Atmos. Chem. Phys., 13, 11019-11058, doi:10.5194/acp-13-11019-2013, 2013.
Lamarque, J. F., Bond, T. C., Eyring, V., Granier, C., Heil, A., Klimont, Z., Lee, D., Liousse, C., Mieville, A., Owen, B., Schultz, M. G., Shindell, D., Smith, S. J., Stehfest, E., Van Aardenne, J., Cooper, O. R., Kainuma, M., Mahowald, N., McConnell, J. R., Naik, V., Riahi, K., and van Vuuren, D. P.: Historical (1850-2000) gridded anthropogenic and biomass burning emissions of reactive gases and aerosols: methodology and application, Atmos. Chem. Phys., 10, 7017-7039, doi:10.5194/acp10-7017-2010, 2010.

Lau, K. M., and Kim, K. M.: Observational relationships between aerosol and Asian monsoon rainfall, and circulation, Geophys. Res. Lett., 33, L21810, doi:10.1029/2006g1027546, 2006.

Lau, W. K. M., Kim, M. K., Kim, K. M., and Lee, W. S.: Enhanced surface warming and accelerated snow melt in the Himalayas and Tibetan Plateau induced by absorbing aerosols, Environ. Res. Lett., 5, 025204, doi:10.1088/1748-9326/5/2/025204, 2010.

Lin, J. T., Youn, D., Liang, X. Z., and Wuebbles, D. J.: Global model simulation of summertime US ozone diurnal cycle and its sensitivity to PBL mixing, spatial resolution, and emissions, Atmos. Environ., 42, 8470-8483, doi:10.1016/j.atmosenv.2008.08.012, 2008.

Lin, J. T., and McElroy, M. B.: Impacts of boundary layer mixing on pollutant vertical profiles in the lower troposphere: Implications to satellite remote sensing, Atmos. Environ., 44, 17261739, doi:10.1016/j.atmosenv.2010.02.009, 2010.

Lin, S. J., and Rood, R. B.: Multidimensional fluxform semi-Lagrangian transport schemes, Mon. Weather Rev., 124, 2046-2070, doi:10.1175/15200493(1996)124<2046:MFFSLT> 2.0.CO;2, 1996.

Liu, H. Y., Jacob, D. J., Bey, I., and Yantosca, R. M.: Constraints from $\mathrm{Pb}-210$ and $\mathrm{Be}-7$ on wet deposition and transport in a global three-dimensional chemical tracer model driven by assimilated meteorological fields, J. Geophys. Res.-Atmos., 106, 12109-12128, doi:10.1029/2000jd900839, 2001.

Liu, J. F., Fan, S. M., Horowitz, L. W., and Levy, H.: Evaluation of factors controlling long-range transport of black carbon to the Arctic, J. Geophys. Res.-Atmos., 116, D04307, doi:10.1029/2010jd015145, 2011.

Louis, J. F.: Parametric Model of Vertical Eddy Fluxes in the Atmosphere, Bound-Lay. Meteorol., 17, 187-202, doi:10.1007/Bf00117978, 1979.

Lu, Z., Zhang, Q., and Streets, D. G.: Sulfur dioxide and primary carbonaceous aerosol emissions in China and India, 1996-2010, Atmos. Chem. Phys., 11, 9839-9864, doi:10.5194/acp-11-98392011, 2011.

Lu, Z. F., Streets, D. G., Zhang, Q., and Wang, S. W.: A novel backtrajectory analysis of the origin of black carbon transported to the Himalayas and Tibetan Plateau during 1996-2010, Geophys. Res. Lett., 39, L01809, doi:10.1029/2011gl049903, 2012.

Ma, L. J., Zhang, T., Frauenfeld, O. W., Ye, B. S., Yang, D. Q., and Qin, D. H.: Evaluation of precipitation from the ERA-40, NCEP-1, and NCEP-2 Reanalyses and CMAP-1, CMAP-2, and GPCP-2 with ground-based measurements in China, J. Geophys Res.-Atmos., 114, D09105, doi:10.1029/2008jd011178, 2009.

Marks, D., Link, T., Winstral, A., and Garen, D.: Simulating snowmelt processes during rain-on-snow over a semiarid mountain basin, Annals of Glaciology, 32, 195-202, doi:10.3189/172756401781819751, 2001. 
Mao, Y. H., Li, Q. B., Zhang, L., Chen, Y., Randerson, J. T., Chen, D., and Liou, K. N.: Biomass burning contribution to black carbon in the Western United States Mountain Ranges, Atmos. Chem. Phys., 11, 11253-11266, doi:10.5194/acp-1111253-2011, 2011.

McMeeking, G. R., Good, N., Petters, M. D., McFiggans, G., and Coe, H.: Influences on the fraction of hydrophobic and hydrophilic black carbon in the atmosphere, Atmos. Chem. Phys., 11, 5099-5112, doi:10.5194/acp-11-5099-2011, 2011.

Ménégoz, M., Gallée, H., and Jacobi, H.-W., Precipitation and snow cover in the Himalaya: From reanalysis to regional climate simulations, Hydrol. Earth Syst. Sci., 17, 3921-3936, doi:10.5194/hess-17-3921-2013, 2013.

Menon, S., Koch, D., Beig, G., Sahu, S., Fasullo, J., and Orlikowski, D.: Black carbon aerosols and the third polar ice cap, Atmos. Chem. Phys., 10, 4559-4571, doi:10.5194/acp-10-4559-2010, 2010.

Mikhailov, E. F., Vlasenko, S. S., Kramer, L., and Niessner, R.: Interaction of soot aerosol particles with water droplets: influence of surface hydrophilicity, J. Aerosol Sci., 32, 697-711, doi:10.1016/S0021-8502(00)00101-4, 2001.

Ming, J., Cachier, H., Xiao, C., Qin, D., Kang, S., Hou, S., and $\mathrm{Xu}, \mathrm{J} .:$ Black carbon record based on a shallow Himalayan ice core and its climatic implications, Atmos. Chem. Phys., 8, 13431352, doi:10.5194/acp-8-1343-2008, 2008.

Ming, J., Xiao, C. D., Cachier, H., Qin, D. H., Qin, X., Li, Z. Q., and $\mathrm{Pu}$, J. C.: Black Carbon (BC) in the snow of glaciers in west China and its potential effects on albedos, Atmos. Res., 92, 114123, doi:10.1016/j.atmosres.2008.09.007, 2009a.

Ming, J., Xiao, C., Du, Z., and Flanner, M. G.,: Black carbon in snow/ice of west China and its radiave forcing, Adv. Climate Change Res., 5(6), 328-35, 2009b (in Chinese with English abstract).

Ming, J., Xiao, C. D., Sun, J. Y., Kang, S. C., and Bonasoni, P.: Carbonaceous particles in the atmosphere and precipitation of the Nam Co region, central Tibet, J. Environ. Sci.-China, 22, 17481756, doi:10.1016/S1001-0742(09)60315-6, 2010.

Ming, J., Du, Z. C., Xiao, C. D., Xu, X. B., and Zhang, D. Q.: Darkening of the mid-Himalaya glaciers since 2000 and the potential causes, Environ. Res. Lett., 7, 014021, doi:10.1088/17489326/7/1/014021, 2012.

Ming, J., Xiao, C. D., Du, Z. C., and Yang, X. G.: An overview of black carbon deposition in High Asia glaciers and its impacts on radiation balance, Advances in Water Resources, 55, 80-87, doi:10.1016/j.advwatres.2012.05.015, 2013.

Moorthi, S., and Suarez, M. J.: Relaxed Arakawa-Schubert - a Parameterization of Moist Convection for General-Circulation Models, Mon. Weather Rev., 120, 978-1002, doi:10.1175/15200493(1992)120<0978:Rasapo> 2.0.Co;2, 1992.

Moorthy, K. K., Beegum, S. N., Srivastava, N., Satheesh, S. K., Chin, M., Blond, N., Babu, S. S., and Singh, S.: Performance evaluation of chemistry transport models over India, Atmos. Environ., 71, 210-225, 2013.

Nair, V. S., Moorthy, K. K., Alappattu, D. P., Kunhikrishnan, P. K., George, S., Nair, P. R., Babu, S. S., Abish, B., Satheesh, S. K., Tripathi, S. N., Niranjan, K., Madhavan, B. L., Srikant, V., Dutt, C. B. S., Badarinath, K. V. S., and Reddy, R. R.: Wintertime aerosol characteristics over the Indo-Gangetic Plain (IGP): Impacts of local boundary layer processes and long-range transport, J. Geophys. Res.-Atmos., 112, D13205, doi:10.1029/2006jd008099, 2007.

Nair, V. S., Solmon, F., Giorgi, F., Mariotti, L., Babu, S. S., and Moorthy, K. K.: Simulation of South Asian aerosols for regional climate studies, J. Geophys. Res.-Atmos., 117, D04209, doi:10.1029/2011JD016711, 2012.

Painter, T. H., Flanner, M. G., Kaser, G., Marzeion, B., VanCuren, R. A., and Abdalati, W.: End of the Little Ice Age in the Alps forced by industrial black carbon, P. Natl. Acad. Sci. USA, 110, 15216-15221, doi:10.1073/pnas.1302570110, 2013.

Park, R. J., Jacob, D. J., Chin, M., and Martin, R. V.: Sources of carbonaceous aerosols over the United States and implications for natural visibility, J. Geophys. Res.-Atmos., 108, 4355, doi:10.1029/2002jd003190, 2003.

Park, R. J., Jacob, D. J., Palmer, P. I., Clarke, A. D., Weber, R. J., Zondlo, M. A., Eisele, F. L., Bandy, A. R., Thornton, D. C., Sachse, G. W., and Bond, T. C.: Export efficiency of black carbon aerosol in continental outflow: Global implications, J. Geophys. Res.-Atmos., 110, D11205, doi:10.1029/2004jd005432, 2005.

Park, R. J., Jacob, D. J., Kumar, N., and Yantosca, R. M.: Regional visibility statistics in the United States: Natural and transboundary pollution influences, and implications for the Regional Haze Rule, Atmos. Environ., 40, 5405-5423, doi:10.1016/j.atmosenv.2006.04.059, 2006.

Pathak, B., Kalita, G., Bhuyan, K., Bhuyan, P. K., and Moorthy, K. K.: Aerosol temporal characteristics and its impact on shortwave radiative forcing at a location in the northeast of India, J. Geophys. Res.-Atmos., 115, D19204, doi:10.1029/2009jd013462, 2010.

Petzold, A., and Schonlinner, M.: Multi-angle absorption photometry - a new method for the measurement of aerosol light absorption and atmospheric black carbon, J. Aerosol Sci., 35, 421-441, doi:10.1016/j.jaerosci.2003.09.005, 2004.

Poschl, U., Letzel, T., Schauer, C., and Niessner, R.: Interaction of ozone and water vapor with spark discharge soot aerosol particles coated with benzo[a]pyrene: $\mathrm{O}_{3}$ and $\mathrm{H}_{2} \mathrm{O}$ adsorption, benzo[a]pyrene degradation, and atmospheric implications, J. Phys. Chem. A., 105, 4029-4041, doi:10.1021/Jp004137n, 2001.

Prasad, A. K., Yang, K. H. S., El-Askary, H. M., and Kafatos, M.: Melting of major Glaciers in the western Himalayas: evidence of climatic changes from long term MSU derived tropospheric temperature trend (1979-2008), Ann. Geophys.-Germany, 27, 45054519, 2009.

Qian, Y., Flanner, M. G., Leung, L. R., and Wang, W.: Sensitivity studies on the impacts of Tibetan Plateau snowpack pollution on the Asian hydrological cycle and monsoon climate, Atmos. Chem. Phys., 11, 1929-1948, doi:10.5194/acp-11-19292011, 2011.

Qin, D. H., Liu, S. Y., and Li, P. J.: Snow cover distribution, variability, and response to climate change in western China, J. Climate, 19, 1820-1833, 2006.

Qin, Y., and Xie, S. D.: Spatial and temporal variation of anthropogenic black carbon emissions in China for the period 19802009, Atmos. Chem. Phys., 12, 4825-4841, doi:10.5194/acp-124825-2012, 2012.

Qu, W. J., Zhang, X. Y., Arimoto, R., Wang, D., Wang, Y. Q., Yan, L. W., and Li, Y.: Chemical composition of the background aerosol at two sites in southwestern and northwestern China: po- 
tential influences of regional transport, Tellus B., 60, 657-673, doi:10.1111/j.1600-0889.2008.00342.x, 2008.

Ram, K., Sarin, M. M., and Hegde, P.: Long-term record of aerosol optical properties and chemical composition from a high-altitude site (Manora Peak) in Central Himalaya, Atmos. Chem. Phys., 10, 11791-11803, doi:10.5194/acp-10-11791-2010, 2010a.

Ram, K., Sarin, M. M., and Tripathi, S. N.: A 1 year record of carbonaceous aerosols from an urban site in the Indo-Gangetic Plain: Characterization, sources, and temporal variability, J. Geophys. Res.-Atmos., 115, D24313, doi:10.1029/2010jd014188, 2010 b.

Ramanathan, V., Chung, C., Kim, D., Bettge, T., Buja, L., Kiehl, J. T., Washington, W. M., Fu, Q., Sikka, D. R., and Wild, M.: Atmospheric brown clouds: Impacts on South Asian climate and hydrological cycle, P. Natl. Acad. Sci. USA, 102, 5326-5333, doi:10.1073/pnas.0500656102, 2005.

Ramanathan, V., Ramana, M. V., Roberts, G., Kim, D., Corrigan, C., Chung, C., and Winker, D.: Warming trends in Asia amplified by brown cloud solar absorption, Nature, 448, 575-578, doi:10.1038/Nature06019, 2007.

Ramanathan, V., and Carmichael, G.: Global and regional climate changes due to black carbon, Nat. Geosci., 1, 221-227, doi:10.1038/Ngeo156, 2008.

Randerson, J. T., Chen, Y., van der Werf, G. R., Rogers, B. M., and Morton, D. C.: Global burned area and biomass burning emissions from small fires, J. Geophys. Res.-Biogeo., 117, G04012, doi:10.1029/2012jg002128, 2012.

Sato, M., Hansen, J., Koch, D., Lacis, A., Ruedy, R., Dubovik, O., Holben, B., Chin, M., and Novakov, T.: Global atmospheric black carbon inferred from AERONET, P. Natl. Acad. Sci. USA, 100, 6319-6324, doi:10.1073/pnas.0731897100, 2003.

Schmid, H., Laskus, L., Abraham, H. J., Baltensperger, U., Lavanchy, V., Bizjak, M., Burba, P., Cachier, H., Crow, D., Chow, J., Gnauk, T., Even, A., ten Brink, H. M., Giesen, K. P., Hitzenberger, R., Hueglin, C., Maenhaut, W., Pio, C., Carvalho, A., Putaud, J. P., Toom-Sauntry, D., and Puxbaum, H.: Results of the "carbon conference" international aerosol carbon round robin test stage I, Atmos. Environ., 35, 2111-2121, doi:10.1016/S1352-2310(00)00493-3, 2001.

Seinfeld, J. H., and S. N. Pandis, Atmospheric Chemistry and Physics, From Air Pollution to Climate Change, 2nd ed., John Wiley, Hoboken, N. J, 490-530, 2006.

Singh, H. B., Brune, W. H., Crawford, J. H., Flocke, F., and Jacob, D. J.: Chemistry and transport of pollution over the Gulf of Mexico and the Pacific: spring 2006 INTEX-B campaign overview and first results, Atmos. Chem. Phys., 9, 2301-2318, 2009, http://www.atmos-chem-phys.net/9/2301/2009/.

Streets, D. G., Bond, T. C., Carmichael, G. R., Fernandes, S. D., Fu, Q., He, D., Klimont, Z., Nelson, S. M., Tsai, N. Y., Wang, M. Q., Woo, J. H., and Yarber, K. F.: An inventory of gaseous and primary aerosol emissions in Asia in the year 2000, J. Geophys. Res.-Atmos., 108, 8809, doi:10.1029/2002jd003093, 2003.

Taylor, K. E.: Summarizing multiple aspects of model performance in a single diagram, J, Geophys, Res,-Atmos,, 106, 7183-7192, doi:10.1029/2000jd900719, 2001.

Textor, C., Schulz, M., Guibert, S., Kinne, S., Balkanski, Y., Bauer, S., Berntsen, T., Berglen, T., Boucher, O., Chin, M., Dentener, F., Diehl, T., Easter, R., Feichter, H., Fillmore, D., Ghan, S., Ginoux, P., Gong, S., Grini, A., Hendricks, J.,
Horowitz, L., Huang, P., Isaksen, I., Iversen, I., Kloster, S., Koch, D., Kirkevåg, A., Kristjansson, J. E., Krol, M., Lauer, A., Lamarque, J. F., Liu, X., Montanaro, V., Myhre, G., Penner, J., Pitari, G., Reddy, S., Seland, Ø., Stier, P., Takemura, T., and Tie, X.: Analysis and quantification of the diversities of aerosol life cycles within AeroCom, Atmos. Chem. Phys., 6, 1777-1813, doi:10.5194/acp-6-1777-2006, 2006.

van der Werf, G. R., Randerson, J. T., Giglio, L., Collatz, G. J., Mu, M., Kasibhatla, P. S., Morton, D. C., DeFries, R. S., Jin, Y., and van Leeuwen, T. T.: Global fire emissions and the contribution of deforestation, savanna, forest, agricultural, and peat fires (19972009), Atmos. Chem. Phys., 10, 11707-11735, doi:10.5194/acp10-11707-2010, 2010.

Voisin, N., Wood, A. W., and Lettenmaier, D. P.: Evaluation of precipitation products for global hydrological prediction, J. Hydrometeorol., 9, 388-407, doi:10.1175/2007jhm938.1, 2008.

Walcek, C. J., Brost, R. A., Chang, J. S., and Wesely, M. L.: So2, Sulfate and Hno3 Deposition Velocities Computed Using Regional Land-Use and Meteorological Data, Atmos. Environ., 20, 949-964, doi:10.1016/0004-6981(86)90279-9, 1986.

Wang, Q., Jacob, D. J., Fisher, J. A., Mao, J., Leibensperger, E. M., Carouge, C. C., Le Sager, P., Kondo, Y., Jimenez, J. L., Cubison, M. J., and Doherty, S. J.: Sources of carbonaceous aerosols and deposited black carbon in the Arctic in winter-spring: implications for radiative forcing, Atmos. Chem. Phys., 11, 1245312473, doi:10.5194/acp-11-12453-2011, 2011.

Wang, Q., Jacob, D. J., Spackman, J. R., Perring, A. E., Schwarz, J. P., Moteki, N., Marais, E. A., Ge, C., Wang, J., and Barrett, S. R. H.: Global budget and radiative forcing of black carbon aerosol: Constraints from pole-to-pole (HIPPO) observations across the Pacific, J. Geophys. Res.-Atmos., 119, 195-206, doi:10.1002/2013jd020824, 2014.

Wang, R., Tao, S., Wang, W. T., Liu, J. F., Shen, H. Z., Shen, G. F., Wang, B., Liu, X. P., Li, W., Huang, Y., Zhang, Y. Y., Lu, Y., Chen, H., Chen, Y. C., Wang, C., Zhu, D., Wang, X. L., Li, B. G., Liu, W. X., and Ma, J. M.: Black Carbon Emissions in China from 1949 to 2050, Environ. Sci. Technol., 46, 7595-7603, doi:10.1021/Es3003684, 2012.

Wang, R., Tao, S., Balkanski, Y., Ciais, P., Boucher, O., Liu, J. F., Piao, S. L., Shen, H. Z., Vuolo, M. R., Valari, M., Chen, H., Chen, Y. C., Cozic, A., Huang, Y., Li, B. G., Li, W., Shen, G. F., Wang, B., and Zhang, Y. Y.: Exposure to ambient black carbon derived from a unique inventory and highresolution model, P. Natl. Acad. Sci. USA., 111, 2459-2463, doi:10.1073/pnas.1318763111, 2014.

Wang, Y. H., Jacob, D. J., and Logan, J. A.: Global simulation of tropospheric O-3-NOx-hydrocarbon chemistry 1. Model formulation, J. Geophys. Res.-Atmos., 103, 1071310725, doi:10.1029/98jd00158, 1998.

Weingartner, E., Saathoff, H., Schnaiter, M., Streit, N., Bitnar, B., and Baltensperger, U.: Absorption of light by soot particles: determination of the absorption coefficient by means of aethalometers, J. Aerosol Sci., 34, 1445-1463, doi:10.1016/S00218502(03)00359-8, 2003.

Wesely, M. L.: Parameterization of Surface Resistances to Gaseous Dry Deposition in Regional-Scale Numerical Models, Atmos. Environ., 23, 1293-1304, doi:10.1016/0004-6981(89)90153-4, 1989. 
Wu, Q. B., and Liu, Y. Z.: Ground temperature monitoring and its recent change in Qinghai-Tibet Plateau, Cold Reg. Sci. Technol., 38, 85-92, doi:10.1016/S0165-232x(03)00064-8, 2004.

Xie, P. P., and Arkin, P. A.: Global precipitation: A 17-year monthly analysis based on gauge observations, satellite estimates, and numerical model outputs, B. Am. Meteorol. Soc., 78, 2539-2558, doi:10.1175/1520-0477(1997)078<2539:Gpayma> 2.0.Co;2, 1997.

Xie, P. P., Yatagai, A., Chen, M. Y., Hayasaka, T., Fukushima, Y., Liu, C. M., and Yang, S.: A Gauge-based analysis of daily precipitation over East Asia, J. Hydrometeorol., 8, 607-626, doi:10.1175/Jhm583.1, 2007.

Xu, B., Yao, T., Liu, X., and Wang, N.: Elemental and organic carbon measurements with a two-step heating-gas chromatography system in snow samples from the Tibetan plateau, Ann. Glaciol., 43, 257-262, doi:10.3189/172756406781812122, 2006.

Xu, B. Q., Cao, J. J., Hansen, J., Yao, T. D., Joswia, D. R., Wang, N. L., Wu, G. J., Wang, M., Zhao, H. B., Yang, W., Liu, X. Q., and He, J. Q.: Black soot and the survival of Tibetan glaciers, P. Natl. Acad. Sci. USA, 106, 22114-22118, doi:10.1073/pnas.0910444106, 2009.

Yasunari, T. J., Bonasoni, P., Laj, P., Fujita, K., Vuillermoz, E., Marinoni, A., Cristofanelli, P., Duchi, R., Tartari, G., and Lau, K. M.: Estimated impact of black carbon deposition during premonsoon season from Nepal Climate Observatory - Pyramid data and snow albedo changes over Himalayan glaciers, Atmos. Chem. Phys., 10, 6603-6615, doi:10.5194/acp-10-6603-2010, 2010.
Zhang, R. Y., Khalizov, A. F., Pagels, J., Zhang, D., Xue, H. X., and McMurry, P. H.: Variability in morphology, hygroscopicity, and optical properties of soot aerosols during atmospheric processing, P. Natl. Acad. Sci. USA, 105, 10291-10296, doi:10.1073/pnas.0804860105, 2008.

Zhang, X. Y., Wang, Y. Q., Zhang, X. C., Guo, W., and Gong, S. L.: Carbonaceous aerosol composition over various regions of China during 2006, J. Geophys. Res.-Atmos., 113, D14111, doi:10.1029/2007jd009525, 2008.

Zhang, Q., Streets, D. G., Carmichael, G. R., He, K. B., Huo, H., Kannari, A., Klimont, Z., Park, I. S., Reddy, S., Fu, J. S., Chen, D., Duan, L., Lei, Y., Wang, L. T., and Yao, Z. L.: Asian emissions in 2006 for the NASA INTEX-B mission, Atmos. Chem. Phys., 9, 5131-5153, doi:10.5194/acp-9-5131-2009, 2009.

Zhao, T. B., and Fu, C. B.: Comparison of products from ERA-40, NCEP-2, and CRU with station data for summer precipitation over China, Adv. Atmos. Sci., 23, 593-604, doi:10.1007/s00376006-0593-1, 2006.

Zhou, G., Yao, T., Kang, S., Pu, J., Tian, L., Yang, W.: Mass balance of the Zhadang glacier in the central Tibetan Plateau. J. Glaciol. Geocryol., 29(3), 360-365, 2007 (in Chinese with English abstract). 